\title{
A systematic literature review of the influence of the university's environment and support system on the precursors of social entrepreneurial intention of students
}

\author{
Carlos Bazan ${ }^{1 *}$ D, Hannah Gaultois², Arifusalam Shaikh ${ }^{3}$, Katie Gillespie ${ }^{4}$, Sean Frederick ${ }^{4}$, Ali Amjad ${ }^{4}$, Simon Yap ${ }^{4}$, \\ Chantel Finn ${ }^{4}$, James Rayner ${ }^{4}$ and Nafisa Belal ${ }^{4}$
}

\author{
* Correspondence: carlos.bazan@ \\ mun.ca \\ ${ }^{1}$ Faculty of Engineering \& Applied \\ Science and Memorial Centre for \\ Entrepreneurship, Memorial \\ University of Newfoundland, 240 \\ Prince Phillips Drive, St. John's, NL \\ A1B 3X5, Canada \\ Full list of author information is \\ available at the end of the article
}

\begin{abstract}
This systematic literature review aims at understanding the influence of the university's environment and support system (ESS) in shaping the social entrepreneurial intention (SEI) of post-secondary education students. Social entrepreneurs play an important role in the economic and social developments of the communities in which they operate, thus many post-secondary institutions are starting to encourage more students to engage in social entrepreneurial behaviour. Consequently, there is a need for systematic approaches to evaluate the impact of various motivational factors related to the university's entrepreneurial ecosystem that could affect the SEl of students. Based on a systematic literature review and narrative synthesis of the antecedents of the SEl of post-secondary education students, the authors proposed a customized SEI model that modifies and extend the one proposed by Hockerts (Entrepreneurship: Theory and Practice, 2017) and Mair and Noboa (Social entrepreneurship, 2006). This study fills a gap in the literature by providing a methodology grounded in theory that can help universities to design their educational and other interventions aimed at encouraging more students to consider social entrepreneurship as a viable career choice after graduation.
\end{abstract}

Keywords: Social entrepreneurial intention, University environment and support system, Student social entrepreneurs, Systematic literature review

\section{Introduction}

This systematic literature review aims at understanding the influence of the university's environment and support system (ESS) in shaping the social entrepreneurial intention (SEI) of post-secondary education students. Social entrepreneurs play an important role in the economic and social developments of the communities in which they operate (Mair \& Noboa, 2006). They are a special type of entrepreneurs who are driven by a variety of motives including the alleviation of poverty, hunger or illiteracy; the improvement of human health; the reparation of social, legal or economic injustice; and the preservation of the environment for future generations (Austin, Stevenson, \& WeiSkillern, 2006; Seelos \& Mair, 2005; Vidal, 2005). Despite their varied motivations, the one common denominator among all social entrepreneurs is the utilization of limited

(c) The Author(s). 2020 Open Access This article is distributed under the terms of the Creative Commons Attribution 4.0 International License (http://creativecommons.org/licenses/by/4.0/), which permits unrestricted use, distribution, and reproduction in any medium, provided you give appropriate credit to the original author(s) and the source, provide a link to the Creative Commons license, and indicate if changes were made. 
resources in new and creative ways to generate social value, as opposed to the maximization of personal and shareholder's wealth (Zadek \& Thake, 1997). Social entrepreneurs are also different from philanthropists in that they do not use their excess wealth to support worthy causes by sponsoring their favourite not-for-profit organizations, but rather mobilize the scarce resources necessary to address a problem that both the free market and government failed to solve (Khanin, 2011). Given the relevance of social entrepreneurs in today's society, many post-secondary institutions are starting to encourage more students to participate in social entrepreneurial initiatives, i.e. to engage in social entrepreneurial behaviour (Hockerts, 2015; Miller, Grimes, Mcmullen, \& Vogus, 2012; Smith, Kickul, \& Coley, 2010). Consequently, there is a need for systematic approaches to evaluate the impact of various motivational factors related to the university's entrepreneurial ecosystem that could shape the SEI of students.

There is evidence in the literature that contextual and situational factors, e.g. the university's ESS, affect entrepreneurial intention by influencing the precursors (antecedents) of intention (Ajzen, 1987; Boyd \& Vozikis, 1994; Krueger \& Carsrud, 1993; Lee \& Wong, 2004; Tubbs \& Ekeberg, 1991). Situational variables typically have an indirect influence on intention by influencing key attitudes and general motivation to behave (Krueger, Reilly, \& Carsrud, 2000). Trivedi (2016) has identified three motivational factors of the university's ESS that could influence the precursors of entrepreneurial intention. He suggested that targeted cognitive and non-cognitive supports, and to a lesser extent the general educational support, seemed to have a positive correlation with the precursors of entrepreneurial intention. Trivedi (2016) also argued that a wellcrafted entrepreneurship education curriculum could significantly improve students' entrepreneurial competencies and raise their enthusiasm to become entrepreneurs. Bazan et al. (2019) have successfully applied a variant of Trivedi's (2016) entrepreneurial intention model to understand the influence of the university's ESS on the precursors of the entrepreneurial intention of students. Following similar rationale, the authors posit that contextual and situational factors such as the university's ESS will also affect the SEI of students. This systematic literature review intends to gather enough evidence to support the aforementioned arguments.

The authors divided the remainder of the article in four sections as follows. "Research methodology" section describes the systematic literature review and narrative synthesis conducted for answering two research questions. "Results" section illustrates the state-of-the knowledge as it pertains to the antecedents of the SEI of students. "Discussion" section describes the proposed SEI model based on the results of the systematic literature review and narrative synthesis and the proposed instrument to operationalize the model. The paper ends with the "Conclusion" section and possible future work.

\section{Research methodology}

The authors conducted a systematic literature review and narrative synthesis of the effect of the university's ESS in shaping the SEI of students. They designed the study as a way to understand the motivational factors related to the university's entrepreneurial ecosystem that could affect the SEI of students (Popay, Roberts, Sowden, \& Petticrew, 2006). There were two research questions guiding the literature review. (1) Does the university's ESS affect the precursors of SEI of students? (2) How did previous studies measure the effect of the university's ESS on the precursors of SEI of students? To 
answer these questions, the authors searched the SCOPUS electronic database platform-the largest citation database of peer-reviewed literature-from inception until October 2018. They used a systematic and repeatable approach to identify relevant publications describing the contents of interest. This included that use of precisely selected words and terms that allowed for a more inclusive search of articles in the database. For replicability, Table 1 provides the key terms, keywords and Boolean expressions used to query the literature.

The query returned 112 publications that met the search criteria, of which 67 documents appeared in scientific or professional journals (articles and reviews), 30 documents were parts of book publications and 15 documents were included in conference proceedings. The authors assumed that journal articles were the only documents validated by peer review, thus these were the only documents included in the literature review (Jones, Coviello, \& Tang, 2011). As a starting point, they conducted a citation analysis to identify the most influential articles within the 67 returned documents. The frequency of citation reflects the importance and quality of the publication as determined by other researchers (Xi, Kraus, Filser, \& Kellermanns, 2013). It is also an indication that the scientific knowledge conveyed in these articles is the foundation of foreground knowledge of more recent articles (Acedo \& Casillas, 2005; Casillas \& Acedo, 2007; Liñán \& Fayolle, 2015). The citation analysis produced a ranking of articles sorted from the most cited to the least cited articles. Five of the authors read the abstracts of the ranked publications for the relevance of the contents and their potential for answering the two research questions. When in doubt, the entire article was read to discern its inclusion. This screening produced 40 documents that were retrieved for further scrutiny. The full text documents were scrutinized independently by three of the authors for whether those studies purposely posited a hypothesis, a research question or conjecture regarding the influence of the university's ESS on the SEI of students. This process revealed that no previous researcher has considered the SEI of students as influenced by the university's ESS per se. Some researchers who studied the influence of the university on the SEI of students did so in relation to the effect of social entrepreneurship education (Adelekan, Williamson, \& Atiku, 2018; Kedmenec, Rebernik, \& Tominc, 2017; Kwong, Thompson, \& Cheung, 2012; Piperopoulos \& Dimov, 2015; Smith \& Woodworth, 2012; Tshikovhi \& Shambare, 2015). Thus, the authors modified the inclusion criteria to contain articles that deal with the SEI of students in more general terms. In other words, articles that used students as subjects of the study, with the purpose of extracting some antecedents related to the university's ESS and their effects on students.

In total, 25 documents met the new inclusion criteria and were examined in extenso by four of the authors. The authors also searched the reference lists of these documents ("snowballing") for additional documents that might meet the inclusion criteria. Three

Table 1 Key terms, keywords and Boolean expressions

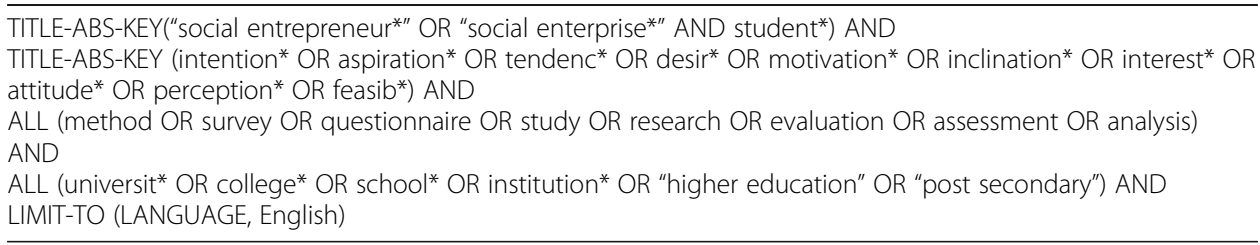


additional documents were retrieved this way. After reading the documents several times by four of the authors and highlighting relevant contents using Qiqqa v.79s, the corresponding author used ATLAS.ti ${ }^{\ominus}$ v.8 to perform open coding to record examples of studies describing (1) precursors of SEI of students, (2) models to assess the SEI of students and (3) results and conclusions. Open coding was useful for identifying, naming, categorizing and describing the relevant contents found in the text. The study then used axial coding to break down the results of the open coding process into core findings that were used to develop the narrative synthesis and answer the research questions. Axial coding was used to relate codes from the open coding to each other, via a combination of inductive and deductive thinking (Long, Strauss, \& Corbin, 2006).

\section{Results}

The authors used tabulation to develop a preliminary synthesis in the literature review process. Tabulation is a common approach used in all types of systematic review to represent both quantitative and qualitative data visually (Popay et al., 2006). Tabulation was useful to develop the initial description of the included studies and to begin to identify patterns across studies. Table 2 provides the preliminary synthesis of results across studies (Forbes \& Griffiths, 2002; Fulop, 2001; Jensen \& Allen, 1996; Jones, 2004). Due to space limitation, Table 2 shows only the hypotheses formulated by the different researchers who used SEI models based on theory, and stated whether rigorous data analysis supported or rejected their proposed hypotheses. Table 2 is followed by a chronological narrative synthesis describing the evolution of the knowledge on the precursors of SEI of students. In the narrative synthesis, the authors included articles where researchers studied the SEI of students and formulated hypotheses, research questions or conjectures on the antecedents of social entrepreneurial intention. Both the tabulated and narrative syntheses informed the development of the proposed model and formulation of the proposed hypotheses that can be used in future studies of the influence of the university's ESS on the SEI of students. Finally, Table 3 summarizes the findings from the tabulation and the narrative synthesis approaches as they relate to the two research questions.

Prieto (2011) was among the first authors to study the precursors of SEI of African American and Hispanic students in the USA. He tried to determine if hope moderates the relationship between a proactive personality and SEI. His findings showed that there exists a positive relationship between having a proactive personality and the SEI of students. However, Prieto's (2011) findings also established that hope did not moderate that relationship. Kirby and Ibrahim (2011) conjectured that if young people are made aware of the concept of social entrepreneurship, recognize its role and importance to society and believe they have the ability to create a new venture, they will do so. They explored awareness of social entrepreneurship of students in Egypt and how the education system might need to adapt to help encourage more students to start social ventures upon graduation. The findings by Kirby and Ibrahim (2011) show that students were aware of the concept but that there was some confusion over what a social entrepreneur is or does.

On subsequent studies, Smith and Woodworth (2012) conjectured that a well-crafted social entrepreneurship course can instil in students both the desire to find solutions to critical social issues and the belief that they have the ability to make a difference. They 
Table 2 Tabulated synthesis of results across different studies

\begin{tabular}{|c|c|c|}
\hline & Hypothesis & Supported? \\
\hline \multirow[t]{2}{*}{ Prieto (2011) } & $\begin{array}{l}\text { "There will be a positive relationship between individuals' proactive } \\
\text { personality and social entrepreneurial intentions." }\end{array}$ & Yes \\
\hline & $\begin{array}{l}\text { "Hope will moderate the relationship between proactive personality } \\
\text { and social entrepreneurial intentions such that the higher the hope } \\
\text { score, the more individuals will have social entrepreneurial } \\
\text { intentions." }\end{array}$ & No \\
\hline $\begin{array}{l}\text { Othman \& Ab Wahid } \\
\text { (2014) }\end{array}$ & $\begin{array}{l}\text { "There is no significant relationship between the SPCSE [specific } \\
\text { personal characteristics of social entrepreneurs] and SEO [social } \\
\text { entrepreneurship organization] among the SIFE [Students in Free } \\
\text { Enterprise] students." }\end{array}$ & Yes \\
\hline Moorthy \& Annamalah & "Perceived social norms have a strong relationship with the & Yes \\
\hline
\end{tabular}
intentions for social entrepreneurship."

"Perceived desirability have a strong relationship with the intentions Yes for social entrepreneurship."

"Perceived self-efficacy have a strong relationship with the intentions Yes for social entrepreneurship."

"Perceived feasibility have a strong relationship with the intentions Yes for social entrepreneurship."

"Perceived propensity to act have a strong relationship with the Yes intentions for social entrepreneurship."

Tshikovhi \& Shambare (2015)

Politis, Ketikidis, Diamantidis, \& Lazuras (2016)

Hockerts (2017)
"Higher levels of entrepreneurial knowledge are positively related to Yes higher levels of personal attitudes."

"Higher levels of entrepreneurial knowledge are positively related to Yes higher levels of entrepreneurial intentions."

"Higher levels of personal attitude are positively related to a higher Yes level of entrepreneurial intentions."

"TPB is able to predict Els as well as SEls."

Yes

"Personality traits determine who demonstrates more inclination No for-social-business creation."

"Demographic characteristics directly affect social—entrepreneurial Yes intentions."

"Situational/environmental or contextual factors directly influence Yes the SEls of people."

"Tensions in mission focus are evident early on in the SEls' formation Yes process."

"Empathy is positively related to social entrepreneurial intentions." Yes

"A perception that societal norms imply a moral obligation to help Yes marginalized people is positively related to social entrepreneurial intentions."

"Social entrepreneurial self-efficacy is positively related to social Yes entrepreneurial intentions."

"Perceived availability of social support is positively related to social Yes entrepreneurial intentions."

"Prior experience with social organizations is positively related to Yes social entrepreneurial intent."

"The link between prior experience and social entrepreneurial intent Yes is mediated by empathy."

"The link between prior experience and social entrepreneurial intent Yes is mediated by perceived moral obligation."

"The link between prior experience and social entrepreneurial intent Yes is mediated by social entrepreneurial self-efficacy."

"The link between prior experience and social entrepreneurial intent Yes is mediated by perceived external social support."

"Social entrepreneurial intentions are positively related to the number Yes 
Table 2 Tabulated synthesis of results across different studies (Continued)

\begin{tabular}{|c|c|c|}
\hline & Hypothesis & Supported? \\
\hline & $\begin{array}{l}\text { of elective courses selected with a social entrepreneurial } \\
\text { profile." }\end{array}$ & \\
\hline & $\begin{array}{l}\text { "Social entrepreneurial intentions are positively related to the } \\
\text { number of elective courses selected with a CSR [corporate social } \\
\text { responsibility] profile." }\end{array}$ & No \\
\hline & $\begin{array}{l}\text { "Social entrepreneurial intentions are positively related to the } \\
\text { number of elective courses selected with an entrepreneurship profile." }\end{array}$ & No \\
\hline \multirow[t]{10}{*}{ Liang et al. (2017) } & $\begin{array}{l}\text { "Extraversion, conscientiousness, and agreeableness positively affect } \\
\text { GSEls [green socio-entrepreneurial intentions]." }\end{array}$ & Yes \\
\hline & "Openness and neuroticism negatively affect GSEls." & Yes \\
\hline & "Bonding social capital positively affects GSEls." & Yes \\
\hline & "Bridging social capital positively affects GSEls." & No \\
\hline & "Entrepreneurial creativity positively affects GSEls." & Yes \\
\hline & $\begin{array}{l}\text { "Extraversion, openness, and neuroticism positively affect } \\
\text { entrepreneurial creativity." }\end{array}$ & Yes \\
\hline & $\begin{array}{l}\text { "Conscientiousness and agreeableness negatively affect } \\
\text { entrepreneurial creativity." }\end{array}$ & No \\
\hline & "Bonding social capital positively affects entrepreneurial creativity." & Yes \\
\hline & "Bridging social capital positively affects entrepreneurial creativity." & No \\
\hline & $\begin{array}{l}\text { "Personality traits and social capital affect GSEls through the } \\
\text { mediation of entrepreneurial creativity." }\end{array}$ & Yes \\
\hline \multirow[t]{12}{*}{$\begin{array}{l}\text { Tiwari, Bhat, \& Tikoria } \\
\text { (2017) }\end{array}$} & $\begin{array}{l}\text { "Attitude towards becoming a social entrepreneur has a positive } \\
\text { effect on social entrepreneurial intentions." }\end{array}$ & Yes \\
\hline & $\begin{array}{l}\text { "Subjective norms have a positive effect on social entrepreneurial } \\
\text { intentions." }\end{array}$ & Yes \\
\hline & $\begin{array}{l}\text { "Perceived behavioural control has a positive effect on social } \\
\text { entrepreneurial intentions." }\end{array}$ & Yes \\
\hline & $\begin{array}{l}\text { "Emotional intelligence has a positive effect on the attitude towards } \\
\text { becoming a social entrepreneur." }\end{array}$ & Yes \\
\hline & $\begin{array}{l}\text { "Emotional intelligence has a positive effect on the subjective } \\
\text { norms." }\end{array}$ & No \\
\hline & $\begin{array}{l}\text { "Emotional intelligence has a positive effect on perceived } \\
\text { behavioural control." }\end{array}$ & No \\
\hline & $\begin{array}{l}\text { "Creativity has a positive effect on the attitude towards becoming a } \\
\text { social entrepreneur." }\end{array}$ & Yes \\
\hline & "Creativity has a positive effect on the subjective norms." & No \\
\hline & "Creativity has a positive effect on perceived behavioural control." & Yes \\
\hline & $\begin{array}{l}\text { "Moral obligation towards helping underprivileged people is } \\
\text { positively related to attitude towards becoming a social } \\
\text { entrepreneur." }\end{array}$ & Yes \\
\hline & $\begin{array}{l}\text { "Moral obligation towards helping underprivileged people is } \\
\text { positively related to subjective norms." }\end{array}$ & No \\
\hline & $\begin{array}{l}\text { "Moral obligation towards helping underprivileged people is } \\
\text { positively related to perceived behavioural control." }\end{array}$ & Yes \\
\hline \multirow[t]{4}{*}{ Kedmenec et al. (2017) } & $\begin{array}{l}\text { "Business students who engage in social entrepreneurship education } \\
\text { perceive social entrepreneurship as more desirable." }\end{array}$ & Yes \\
\hline & $\begin{array}{l}\text { "Business students who engage in social entrepreneurship education } \\
\text { perceive social entrepreneurship as more feasible." }\end{array}$ & Yes \\
\hline & $\begin{array}{l}\text { "Business students with more experience in prosocial behaviour } \\
\text { perceive social entrepreneurship as more desirable." }\end{array}$ & Yes \\
\hline & "Business students with more experience in prosocial behaviour & Yes \\
\hline
\end{tabular}


Table 2 Tabulated synthesis of results across different studies (Continued)

\begin{tabular}{|c|c|c|}
\hline & Hypothesis & Supported? \\
\hline \multirow[t]{12}{*}{ Aure (2018) } & $\begin{array}{l}\text { "Prior experience has a direct positive influence on social } \\
\text { entrepreneurial intent." }\end{array}$ & Yes \\
\hline & $\begin{array}{l}\text { "Prior experience, mediated by empathy, moral obligation, self- } \\
\text { efficacy and social support, has significant positive indirect influence } \\
\text { on intention." }\end{array}$ & Yes \\
\hline & $\begin{array}{l}\text { "Empathy has a significant positive influence on social } \\
\text { entrepreneurial intent." }\end{array}$ & Yes \\
\hline & $\begin{array}{l}\text { "Moral obligation has a significant positive influence on social } \\
\text { entrepreneurial intent." }\end{array}$ & No \\
\hline & $\begin{array}{l}\text { "Self-efficacy has a significant positive influence on social } \\
\text { entrepreneurial intent." }\end{array}$ & Yes \\
\hline & $\begin{array}{l}\text { "Perceived social support has a significant positive influence on } \\
\text { social entrepreneurial intent." }\end{array}$ & Yes \\
\hline & $\begin{array}{l}\text { "The big five personality traits, mediated by empathy, moral } \\
\text { obligation, self-efficacy, and social support, have significant positive } \\
\text { indirect influence on social entrepreneurial intent." }\end{array}$ & Yes \\
\hline & $\begin{array}{l}\text { "Grit, mediated by empathy, moral obligation, self-efficacy, and social } \\
\text { support, has a significant positive indirect influence on social } \\
\text { entrepreneurial intent." }\end{array}$ & Yes \\
\hline & $\begin{array}{l}\text { "Prior exposure to social action programs, mediated by empathy, } \\
\text { moral obligation, self-efficacy, and social support, has a significant } \\
\text { positive indirect influence on social entrepreneurial intent." }\end{array}$ & No \\
\hline & $\begin{array}{l}\text { "Prior exposure to social action programs, mediated by moral } \\
\text { obligation, has a significant positive influence on social } \\
\text { entrepreneurial intent." }\end{array}$ & No \\
\hline & $\begin{array}{l}\text { "Prior exposure to social action programs, mediated by self-efficacy, } \\
\text { has a significant positive influence on social entrepreneurial intent." }\end{array}$ & No \\
\hline & $\begin{array}{l}\text { "Prior exposure to social action programs, mediated by perceived } \\
\text { social support, has a significant positive influence on social } \\
\text { entrepreneurial intent." }\end{array}$ & No \\
\hline \multirow[t]{10}{*}{ Bacq \& Alt (2018) } & $\begin{array}{l}\text { "Perspective-taking is positively related to social entrepreneurial } \\
\text { self-efficacy." }\end{array}$ & Yes \\
\hline & $\begin{array}{l}\text { "Empathic concern is positively related to social entrepreneurial } \\
\text { self-efficacy." }\end{array}$ & Yes \\
\hline & $\begin{array}{l}\text { "Social entrepreneurial self-efficacy is positively related to social } \\
\text { entrepreneurial intentions." }\end{array}$ & Yes \\
\hline & $\begin{array}{l}\text { "Social entrepreneurial self-efficacy mediates the relationship } \\
\text { between perspective-taking and social entrepreneurial intentions." }\end{array}$ & Yes \\
\hline & $\begin{array}{l}\text { "Social entrepreneurial self-efficacy mediates the relationship } \\
\text { between empathic concern and social entrepreneurial intentions." }\end{array}$ & Yes \\
\hline & "Perspective-taking is positively related to social worth." & Yes \\
\hline & "Empathic concern is positively related to social worth." & No \\
\hline & $\begin{array}{l}\text { "Social worth is positively related to social entrepreneurial } \\
\text { intentions." }\end{array}$ & Yes \\
\hline & $\begin{array}{l}\text { "Social worth mediates the relationship between perspective-taking } \\
\text { and social entrepreneurial intentions." }\end{array}$ & Yes \\
\hline & $\begin{array}{l}\text { "Social worth mediates the relationship between empathic concern } \\
\text { and social entrepreneurial intentions." }\end{array}$ & No \\
\hline \multirow[t]{4}{*}{ Ip, Wu, Liu, \& Liang (2018) } & "Empathy positively affects SEI through entrepreneurial creativity." & No \\
\hline & $\begin{array}{l}\text { "Moral obligation negatively affects SEl through the mediation of } \\
\text { entrepreneurial creativity." }\end{array}$ & Yes \\
\hline & $\begin{array}{l}\text { "Self-efficacy positively affects SEl through the mediation of } \\
\text { entrepreneurial creativity." }\end{array}$ & Yes \\
\hline & "Perceived social support positively affects SEI through & Yes \\
\hline
\end{tabular}


Table 2 Tabulated synthesis of results across different studies (Continued)

\begin{tabular}{|c|c|c|}
\hline & Hypothesis & Supported? \\
\hline & the mediation of entrepreneurial creativity." & \\
\hline & $\begin{array}{l}\text { "Prior experience positively affects SEl through the mediation of } \\
\text { empathy, moral obligation, self-efficacy, perceived social support, } \\
\text { and entrepreneurial creativity." }\end{array}$ & Yes \\
\hline \multirow[t]{3}{*}{ Adelekan et al. (2018) } & $\begin{array}{l}\text { "A significant positive relationship between social entrepreneurship } \\
\text { pedagogy and students' behavioural outcomes in selected Nigerian } \\
\text { universities." }\end{array}$ & Yes \\
\hline & $\begin{array}{l}\text { "Students' attitudes mediate the relationship between social } \\
\text { entrepreneurship pedagogy and students' behavioural outcomes." }\end{array}$ & Yes \\
\hline & $\begin{array}{l}\text { "A significant positive relationship between social entrepreneurship } \\
\text { pedagogy and students' intentions towards creating a social } \\
\text { venture." }\end{array}$ & Yes \\
\hline \multirow[t]{6}{*}{ Ip, Wu, et al. (2018) } & $\begin{array}{l}\text { "Extraversion, openness to experience, conscientiousness and } \\
\text { agreeableness positively affect social entrepreneurial intentions." }\end{array}$ & No \\
\hline & "Neuroticism negatively affects social entrepreneurial intentions." & No \\
\hline & "Originality positively affects social entrepreneurial intentions." & Yes \\
\hline & "Usefulness positively affects social entrepreneurial intentions." & No \\
\hline & $\begin{array}{l}\text { "Bridging social capital positively affects social entrepreneurial } \\
\text { intentions." }\end{array}$ & No \\
\hline & $\begin{array}{l}\text { "Bonding social capital positively affects social entrepreneurial } \\
\text { intentions." }\end{array}$ & No \\
\hline \multirow[t]{5}{*}{ Luc (2018) } & $\begin{array}{l}\text { "Attitude towards behaviour is positively associated with social } \\
\text { entrepreneurship intention." }\end{array}$ & Yes \\
\hline & $\begin{array}{l}\text { "Subjective norms are positively associated with social } \\
\text { entrepreneurship intention." }\end{array}$ & No \\
\hline & $\begin{array}{l}\text { "Perceived behavioural control is positively associated with social } \\
\text { entrepreneurship intention." }\end{array}$ & Yes \\
\hline & $\begin{array}{l}\text { "Perceived access to finance increases social entrepreneurship } \\
\text { intention." }\end{array}$ & No \\
\hline & $\begin{array}{l}\text { "Perceived access to finance increases social entrepreneurship } \\
\text { intention through the determinants of planned behaviour as } \\
\text { mediator." }\end{array}$ & Yes \\
\hline Shahverdi, Ismail, \& & "Lack of support has a negative effect on social entrepreneurial & No \\
\hline
\end{tabular}

Qureshi (2018)

Barton, Schaefer, \& Canavati (2018) intention."

"Lack of knowledge has a negative effect on social entrepreneurial intention."

"Lack of competency has a negative effect on social entrepreneurial Yes intention."

"Lack of self-confidence has a negative effect on social entrepreneurial Yes intention."

"Lack of resources has a negative effect on social entrepreneurial Yes intention.

"Social entrepreneurial education moderates the relationship Yes between the perceived barriers and social entrepreneurial intention."

"A positive relationship exists between perceived desirability and the Yes intention to establish a social enterprise."

"A positive relationship exists between perceived feasibility and the Yes intention to establish a social enterprise."

"A positive relationship exists between entrepreneurial experience Yes and the intention to establish a social enterprise."

"A positive relationship exists between entrepreneurial education Yes and the perceived feasibility of establishing a social enterprise."

"A positive relationship exists between entrepreneurial self-efficacy Yes and perceived feasibility of establishing a social enterprise." 
Table 2 Tabulated synthesis of results across different studies (Continued)

\begin{tabular}{|c|c|}
\hline Hypothesis & Supported? \\
\hline $\begin{array}{l}\text { "A positive relationship exists between internal locus of control and } \\
\text { perceived feasibility of establishing a social enterprise." }\end{array}$ & Yes \\
\hline $\begin{array}{l}\text { "A positive relationship exists between the desire to make an impact } \\
\text { and the perceived desirability of establishing a social enterprise." }\end{array}$ & Yes \\
\hline $\begin{array}{l}\text { "A positive relationship exists between the need for financial success } \\
\text { and the perceived desirability of establishing a social enterprise." }\end{array}$ & No \\
\hline $\begin{array}{l}\text { "A positive relationship exists between the need for self-realization } \\
\text { and the perceived desirability of establishing a social enterprise." }\end{array}$ & Yes \\
\hline $\begin{array}{l}\text { "A positive relationship exists between the need for authority and } \\
\text { the perceived desirability of establishing a social enterprise." }\end{array}$ & No \\
\hline $\begin{array}{l}\text { "A positive relationship exists between the need for autonomy and } \\
\text { the perceived desirability of establishing a social enterprise." }\end{array}$ & Yes \\
\hline $\begin{array}{l}\text { "A positive relationship exists between the need for challenge and } \\
\text { the perceived desirability of establishing a social enterprise." }\end{array}$ & No \\
\hline
\end{tabular}

provided multiple anecdotal examples of specific course contents and group projects that have led to active student engagement in social entrepreneurial endeavours. Kwong et al. (2012) conducted a pedagogical study to explore the effectiveness of social business plan teaching in inducing social and civic awareness and intentionality among business students. They compared social business plan teaching with the more traditional case study approach. Their study found that both approaches can be successful in raising awareness and improving the attitudes of participating students. Prieto, Phipps and Friedrich (2012) assessed the SEI of African-American and Hispanic students in the USA using a SEI scale modified from an entrepreneurial decision scale by Chen, Greene and Crick (1998). They concluded that African-American and Hispanic students possess low intentions to become social entrepreneurs.

Afterwards, Salamzadeh, Azimi and Kirby (2013) investigated awareness, intention/ support and the contextual elements among students in Iran in order to find the gaps in social entrepreneurship education. Their survey was conducted in three different

Table 3 Summary of findings as they relate to the research questions

\begin{tabular}{|c|c|}
\hline Research question & Finding \\
\hline $\begin{array}{l}\text { 1) Does the university's ESS affect the precursors of } \\
\text { SEl of students? }\end{array}$ & $\begin{array}{l}\text { To the best of the authors' knowledge, no previous } \\
\text { study has considered the SEl of students as influenced } \\
\text { by the university's ESS. Some researchers studied the } \\
\text { influence of the university on the SEl of students in } \\
\text { relation to social entrepreneurship education (Adelekan } \\
\text { et al., 2018; Kedmenec et al., 2017; Kwong et al., 2012; } \\
\text { Piperopoulos \& Dimov, 2015; Smith \& Woodworth, } \\
\text { 2012; Tshikovhi \& Shambare, 2015). Radin, Rahman, } \\
\text { Othman and Pihie (2017) found that public university } \\
\text { students have a higher potential to become social } \\
\text { entrepreneurs as compared to those from private } \\
\text { universities. Thus, the university's ESS has the capacity } \\
\text { to influence the precursors of SEl. }\end{array}$ \\
\hline $\begin{array}{l}\text { 2) How did previous studies measure the effect of } \\
\text { the university's ESS on the precursors of SEl of } \\
\text { students? }\end{array}$ & $\begin{array}{l}\text { Politis et al. (2016) concluded that SEl is shaped in the } \\
\text { same way as commercial entrepreneurial intention. } \\
\text { Thus, SEl can be assessed with similar models, e.g. } \\
\text { based on Ajzen's (1991) TPB. Bazan et al. (2019) have } \\
\text { successfully applied a variant of Trivedi's (2016) } \\
\text { entrepreneurial intention model to understand the } \\
\text { influence of the university's ESS on the precursors of } \\
\text { the commercial entrepreneurial intention of students. }\end{array}$ \\
\hline
\end{tabular}


faculties (entrepreneurship, management and engineering), to evaluate the SEI of students and to capture varied orientations. Their findings show significant awareness of the concept and high SEI among students but a lack of sufficient attention to contextual elements and adequate support. Othman and Ab Wahid (2014) identified the social entrepreneurship dimensions that emphasize the specific personal characteristics of social entrepreneurs among students in the Students in Free Enterprise program in Malaysia. Their findings suggest a strong positive relationship between specific personal characteristics of social entrepreneurs and students in the program. Moorthy and Annamalah (2014) examined the SEI of students in Malaysia. In order of importance, they found that the following elements are influential in the formation of intention to start a social enterprise: social support, willpower, experience, empathy and regional factors surrounding the students.

Next, Tshikovhi and Shambare (2015) tested the association among practical entrepreneurship training (as operationalized by participation in Enactus projects), personal attitudes, entrepreneurial knowledge and SEI of students in South Africa. Findings of their study indicated that both entrepreneurial knowledge and personal attitude have significant influence on SEI. Tshikovhi and Shambare (2015) also found that personal attitude has a stronger influence on the SEI of students, while entrepreneurial knowledge seems to positively influence the personal attitudes of students. Konakll (2015) tried to determine the effects of self-efficacy on the social entrepreneurship characteristics of pre-services teachers (students) in Turkey. Her results revealed that effort and persistence-which are general self-efficacy dimensions-predicted personal creativity and risk-taking features of social entrepreneurship. According to her findings, the initiative, effort and persistence dimensions predict the self-confidence, which is a characteristic of social entrepreneurs. Shek and Lin (2015) identified the attributes of successful social entrepreneurs and suggested ways in which students in Hong Kong can be nurtured to become social entrepreneurs. They concluded that leadership competence, moral character and caring dispositions are the three attributes of a successful service leader.

Successively, Ashour (2016) explored the attitudes towards business and social entrepreneurship of students in the United Arab Emirates. She conjectured that the lack of awareness among students regarding social entrepreneurship and the lack of education opportunities in this particular field are adversely affecting students' attitudes towards these areas. Ashour (2016) concluded that there is a gap between students' entrepreneurial aspirations on the one hand and their readiness in terms of training and education on the other hand. Sezen-Gultekin and Gur-Erdogan (2016) sought to determine the relation between the lifelong learning tendency and social entrepreneurship characteristics (and vice versa) of pre-service teachers (students). Results of their analysis determined that there is a significant relationship between lifelong learning tendencies and social entrepreneurship characteristics of students. Furthermore, their study also found a moderate positive and significant relationship between lifelong learning tendencies and personal creativity, self-reliance and risk taking-which are sub-dimensions of social entrepreneurship. Politis et al. (2016) investigated if SEI is shaped in the same way as entrepreneurial intentions by assessing the extent to which Ajzen's (1991) theory of planned behaviour (TPB) could be applied to SEI of students in the South-East European region. They also probed the factors that directly correlate to SEI and 
whether they are the same as those that directly correlate to entrepreneurial intentions. Their study found that the TPB was successful at predicting both social and commercial entrepreneurial intentions of students.

More recently, Hockerts (2017) tested the SEI model proposed by Mair and Noboa (2006) to predict the SEI of students in a Scandinavian business school. He also extended the model by including prior experience with social problems as an additional variable. Hockerts' (2017) findings show that prior experience predicts SEI, and that this effect is mediated by the precursors suggested by Mair and Noboa (2006). His findings also suggest that social entrepreneurial self-efficacy has both the largest impact on intentions as well as being itself most responsive to prior experience. Liang et al. (2017) conducted two studies to analyse how personality traits, entrepreneurial creativity and social capital affect green socio-entrepreneurial intentions of students in Taiwan and Hong Kong. Their first study was conducted to confirm the factor structures of the scales, namely the five-factor model of personality traits (Thompson, 2008), entrepreneurial creativity (Chia \& Liang, 2016), social capital (Williams, 2006) and green socioentrepreneurial intentions (Wang, Chang, Yao, \& Liang, 2016). Their second study built predictive models to compare students in Taiwan and Hong Kong. Findings of their first study confirmed the factor structures of the four scales that Liang et al. (2017) used in their study. Results of their second study revealed that though the effects of predictor variables on the outcome variable were varied, the mediation models of entrepreneurial creativity across contexts were partially supported. Tiwari et al. (2017) tried to assess the SEI of students in India as influenced by emotional intelligence and selfefficacy. Their results show that their proposed model can explain SEI and that both emotional intelligence and self-efficacy showed positive significant relationship with both attitude and the SEI of students. Huster et al. (2017) conducted a program evaluation to assess the outcome of students' participation in a social entrepreneurship competition. This evaluation strongly suggests that social entrepreneurship competitions can contribute to training and educating in multiple and important ways.

Also recently, Radin et al. (2017) studied SEI and its differences among students and alumni and university categories (e.g. public and private university) in Malaysia. Their results revealed that the level of the SEI of students and alumni was moderate and very similar to each other, and that public university students have a higher potential to become social entrepreneurs as compared to those from private universities. Chipeta and Surujlal (2017) investigated the influence of attitude, risk taking propensity and proactive personality on SEI of students in South Africa. Their results showed that only risk-taking propensity and attitude towards entrepreneurship were significant, with risk taking propensity being the most significant. Their results also showed that proactive personality did not make a unique contribution to the SEI of students. Kedmenec et al. (2017) examined the association between social entrepreneurship education and experience in prosocial behaviour on the one hand, and the perceived desirability and feasibility of social entrepreneurship among business students on the other hand. Their results indicate a significant positive association between the "know what" (awareness) component of social entrepreneurship education and both the desirability and the feasibility of social entrepreneurship. Findings of their study also indicate a significant positive association between the "know how" (self-efficacy) component of social entrepreneurship education and the feasibility of social entrepreneurship. Furthermore, they concluded 
that experience in prosocial behaviour has a significant positive association with both the desirability and the feasibility of social entrepreneurship.

In some of the latest reports, Lacap, Mulyaningsih and Ramadani (2018) investigated how the SEI antecedents directly and indirectly affect SEI of students in Indonesia and the Philippines. Their results revealed that prior experience with social problems positively and significantly affects empathy, moral obligation, social entrepreneurial selfefficacy and perceived social support. They also found that social entrepreneurial selfefficacy and perceived social support positively and significantly affect SEI, and that these two antecedents mediate the positive relationship between prior experience with social problems and SEI. Aure (2018) used the studies by Hockerts (2017) and Mair and Noboa (2006) to explore the SEI of students in the Philippines. He extended Hockerts' (2017) SEI model by examining grit, agreeableness and prior exposure to social action programs as antecedents that he hypothesised to be mediated by empathy, moral obligation, social entrepreneurial self-efficacy and perceived social support. Aure's (2018) findings showed that the relationship of SEI with agreeableness are mediated by empathy, self-efficacy and perceived social support. Self-efficacy and social support mediated grit and SEI. Bacq and Alt (2018) proposed that empathy explains SEI through two complementary mechanisms: self-efficacy (an agentic mechanism) and social worth (a communal mechanism). Their results provided a novel explanation of the mechanisms through which empathy, both cognitive and affective, motivates SEI by building on the prosocial motives literature and on the psychological distinction between individual agency and communal motives. Ip, Liang, Wu, Law and Liu (2018) proposed a multiple mediation framework to examine the mediating role of entrepreneurial creativity for students in Taiwan and Hong Kong. Results of their study confirmed that prior experience with social problems, perceived social support and originality are the three most influential factors affecting the SEI of students.

Also very recently, Adelekan et al. (2018) examined the influence of social entrepreneurship pedagogy on the behavioural outcomes of students in Nigeria with regards to their attitudes, intentions and behaviours towards the creation of a social venture. Their results point to a significant positive relationship between social entrepreneurial pedagogy and students behavioural outcomes. Their results show that pedagogical contents exert the greatest influence on the SEI of students. They also found that students' attitudes mediate the relationship between social entrepreneurial pedagogy and students' behavioural outcomes. Ip, Wu et al. (2018) examined whether personality traits, creativity and social capital affect SEI of students in Hong Kong. Their analysis revealed that openness negatively predicted SEI, while originality positively predicted SEI. However, they found no direct association between social capital and SEI. Luc (2018) developed an integrated model based on the TPB to examine the direct and indirect effect of perceived access to financial resources on SEI. He found no direct relationship between perceived access to financial resources and SEI. Perceived access to financial resources only indirectly increases SEI through attitude towards behaviour and perceived behavioural control. Shahverdi et al. (2018) used the TPB as a framework to investigate the barriers of SEI of students in Malaysia. Findings of their study show that the lack of competency, self-confidence and resources were the barriers affecting SEI. Their results also show that social entrepreneurial education moderated the relationship between the perceived barriers and the SEI of students. Barton et al. (2018) investigated the process 
of content-based and process-based motivational needs influencing the SEI of students in the USA. For the process-based motives, they found that perceived feasibility and perceived desirability to start a social enterprise as well as exposure to entrepreneurship are significant predictors of the SEI of students. In addition, they found that perceived feasibility is determined by entrepreneurship education and entrepreneurial selfefficacy, and perceived desirability is determined by students' desire for self-realisation and autonomy. For the content-based motives, they found that students are motivated by the need for achievement and independence.

Table 3 summarizes the findings from the tabulation and narrative synthesis above as they help to answer the two research questions.

\section{Limitations of the literature review}

The methodology employed in this literature review has strengths and limitations. A strength of the literature review is the use of systematic methods for searching and synthesizing the current literature to answer the research questions. However, the literature review is limited by the key terms and keywords used to retrieve the desired information. Consequently, the authors acknowledge that there might exist very good sources that were not included in the synthesis. The rationale for choosing the key terms and keywords in the search was to identify a deliberate intent on the part of previous authors. That is, the authors wanted to learn from other researchers who deliberately intended to communicate about the influence of the university's ESS on the SEI of students. Another limitation of the study is that the search strategy was restricted to English language publications. This might have introduced a bias in favour of studies conducted in English-speaking countries and institutions.

\section{Discussion}

The large majority of the studies on SEI of students included in this systematic literature review are based on Ajzen's (1991) TPB as modified by Mair and Noboa (2006) (Aure, 2018; Bacq \& Alt, 2018; Barton et al., 2018; Hockerts, 2015, 2017; Ip, Wu, et al., 2018; Luc, 2018; Moorthy \& Annamalah, 2014; Politis et al., 2016; Tiwari et al., 2017). Choosing a career is a decision that requires certain degree of cognitive processing and some amount of planning (Kautonen, van Gelderen, \& Tornikoski, 2013; Krueger, 2005). Becoming self-employed or starting a new business, e.g. a social enterprise, represents a career choice and thus falls under the category of planned behaviour, which is best described and predicted by intention rather than by responses to external stimuli (Davidsson, 1991; Katz, 1994; Krueger et al., 2000; Lent, Brown, \& Hackett, 1994; Thompson, 2009). Intention is the single best predictor of the person's behaviour and as such, it is a significant and unbiased predictor of career choice (Fishbein \& Ajzen, 1975; Lent et al., 1994). Drawing from social and cognitive psychology and based on Ajzen's (1991) TPB, Mair and Noboa (2006) adapted the model of entrepreneurial intention proposed by Krueger and Carsrud (1993) and Krueger et al. (2000) and translated it to the context of social entrepreneurship. The TPB is a robust and parsimonious model of behavioural intention with proven power in predicting entrepreneurial behaviour (Kautonen et al., 2013; Kautonen, van Gelderen, \& Fink, 2015; Moriano, Gorgievski, Laguna, Stephan, \& Zarafshani, 2012). Intention models based on TPB offer 
a sound theoretical framework that can specifically map out the nature of processes underlying intentional entrepreneurial behaviour (Kim \& Hunter, 1993; Krueger et al., 2000).

Great amount of cross-disciplinary research has been devoted to testing, advancing and criticizing the TPB-based models (Armitage \& Conner, 2001; Sheeran, 2005). The main hypothesis behind the TPB relies on the idea that intention has three conceptually different precursors, i.e. attitude towards the behaviour (ATB), suggestive social norm (SSN) and perceived behavioural control (PBC) (Ajzen, 1991; Varamäki et al., 2013). In principle, understanding the three precursors of intention should be sufficient to predict behaviour (Ajzen \& Fishbein, 2004). However, the TPB does allow for the three theoretical precursors to vary greatly in intensity and for them to exert certain degree of influence on each other depending on context (Varamäki et al., 2013). In addition, demographics and other characteristics related to the person's background are not specifically included in the TPB. The TPB expects these factors to have only indirect impact on intention through their influence on the three precursors of intention (Boyd \& Vozikis, 1994; Kolvereid, 1996b; Krueger \& Carsrud, 1993; Lee \& Wong, 2004; Tubbs \& Ekeberg, 1991).

Given its robustness, the TPB has become one of the most widely used psychological theories for explaining and predicting human behaviour in general (Kolvereid, 1996b; Tkachev \& Kolvereid, 1999; Varamäki et al., 2013). The models based on this theory have been successfully used in the entrepreneurial context to predict the specific behaviour of starting a new business (Kautonen et al., 2013, 2015; Kolvereid, 1996a, 1996b; Krueger \& Carsrud, 1993). Also, it has been successfully used to assess the entrepreneurial intention of students in very different cultural settings (Autio, Keeley, Klofsten, Parker, \& Hay, 2001; Devonish, Alleyne, Charles-Soverall, Young Marshall, \& Pounder, 2010; Fayolle, Gailly, Lassas-Clerc, \& Lassas-Clerc, 2006; Iakovleva, Kolvereid, \& Stephan, 2011; Kolvereid, 1996b; Krueger et al., 2000; Krueger \& Carsrud, 1993; Tkachev \& Kolvereid, 1999). Findings by previous studies support the claim that all three precursors of intention are important, but not in every situation and not to the same degree (Ajzen, 1991; Varamäki et al., 2013). Nonetheless, the TPB captures the three precursors of entrepreneurial intention which would indicate the amount of effort that the person will make to carry out the behaviour (Ajzen, 1991; Liñán, 2004; Liñán \& Chen, 2009):

Mair and Noboa (2006) proposed that, similar to commercial entrepreneurs, social entrepreneurs develop their intention to start a social enterprise after experiencing the perception of feasibility (PBC) and desirability (ATB) and a propensity to act (Shapero \& Sokol, 1982). Furthermore, they also identified willpower, support and the recognition of opportunity as important precursors of perceptions of feasibility and desirability, and a propensity to act. Moreover, Mair and Noboa (2006) proposed that social sentiments will influence willpower, support and the recognition of opportunity. Hockerts (2015) developed and validated measures of four of the constructs identified by Mair and Noboa (2006) as antecedents of SEI. He redefined the antecedents as empathy with marginalized people, a feeling of moral obligation to help marginalized people, a high level of self-efficacy concerning the ability to effect social change and perceived availability of social support. Hockerts (2015) was able to demonstrate nomological validity by showing that, as specified by Mair and Noboa (2006), empathy and moral obligation 
are positively associated with perceived desirability and self-efficacy, and social support with perceived feasibility of starting a social venture. More recently, Hockerts (2017) refined his previous work and tested the model of SEI proposed by Mair and Noboa (2006) and included prior experience with social problems as an additional variable.

As part of the findings of this systematic literature review and as a way to assess the SEI of students, the authors adopted, adapted and extended Hockerts' (2017) work to propose a SEI model for students. The authors are interested in exploring the relative importance of the precursors of SEI as influenced by university's ESS, i.e. entrepreneurial ecosystem. Thus, they propose the model of SEI depicted in Fig. 1. This model specifies and describes the governing rules and measurement properties of the observed variables.

In Fig. 1, empathy towards others (ETO) is a proxy for ATB of the TPB. In the TPB, ATB refers to the degree to which the person has a favourable (or unfavourable) assessment of the behaviour (desirability). For example, a positive attitude towards the behaviour of starting a new business should lead to a stronger intention to go ahead and start a new business (Ajzen, 2001; Autio et al., 2001; Kolvereid, 1996b; Krueger et al., 2000; Pruett, Shinnar, Toney, Llopis, \& Fox, 2009; Segal, Borgia, \& Schoenfeld, 2005; Shapero \& Sokol, 1982; van Gelderen \& Jansen, 2006; Varamäki et al., 2013). Previous studies have established ATB to be significant and among the most influential constructs in explaining the intention to start a new venture (Bazan et al., 2019; Harris \& Gibson, 2008; Liñán \& Chen, 2006; Watchravesringkan et al., 2013). Empathy has been extensively studied in the context of helping behaviour (Borman, Penner, Allen, \& Motowidlo, 2001; Oswald, 1996). Empathy is an essential trait of social entrepreneurs (Dees, 2012) and similar to ATB, it has been regarded as an important antecedent of SEI (Dees, 2012; London, 2010; Mair \& Noboa, 2006; Miller et al., 2012). ETO as a precursor of SEI is based on the premise that desirability will develop after a person is able to imagine the feelings or mental state of another person in need of compassion (Goetz, Keltner, \& Simon-Thomas, 2010; Mehrabian \& Epstein, 1972; Preston et al., 2007). It is also based on the premise that individuals with high levels of empathy are more likely to develop intentions to become social entrepreneurs as a way to assist others in need

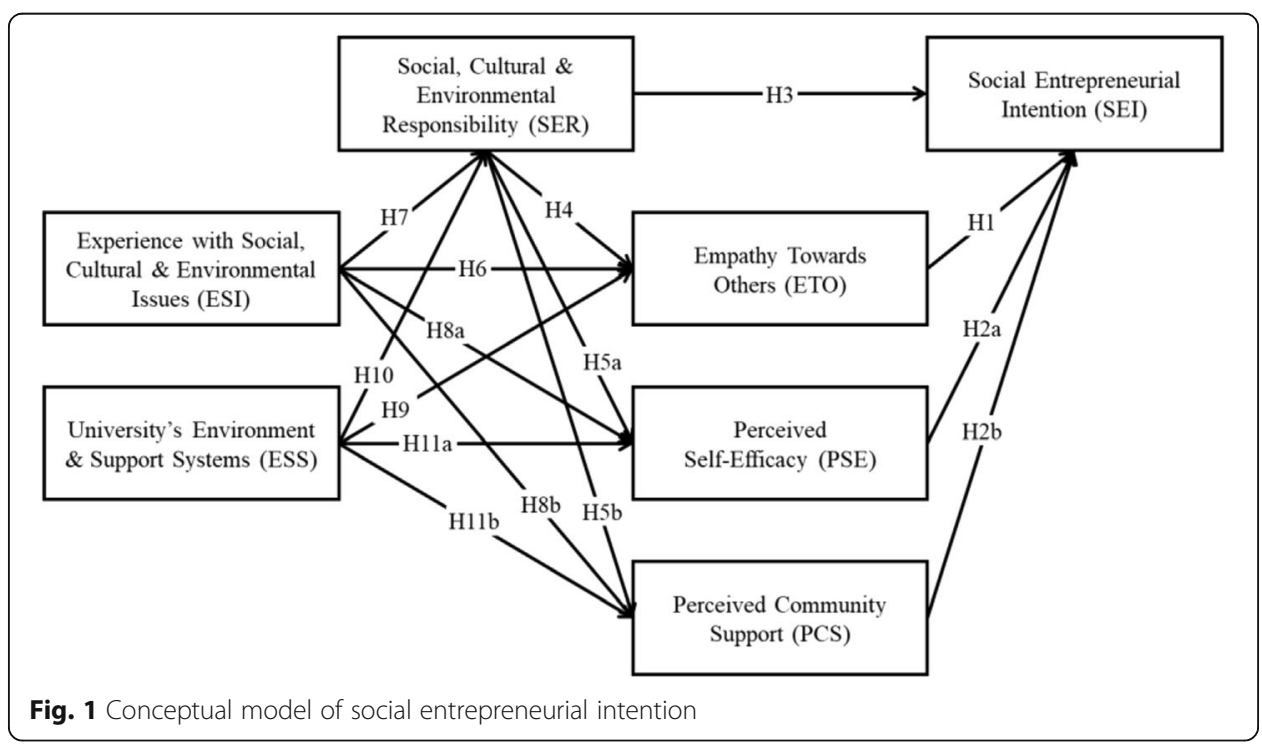


(Bacq \& Alt, 2018). In Hockerts' (2017) work, ETO includes both cognitive empathy and emotional empathy, or the ability to recognize and propensity to react to another person's emotional state. Thus, the authors formulate the following hypothesis:

H1: Empathy towards others positively influences social entrepreneurial intention.

Perceived self-efficacy (PSE) and perceived community support (PCS) are proxies for $\mathrm{PBC}$ in the TPB, i.e. internal and external loci of control. $\mathrm{PBC}$ refers to the overall perceived level of ease (or difficulty) of performing the behaviour (feasibility). PBC is concerned with the presence (or absence) of requisite resources and opportunities for performing the behaviour, and how these are perceived to be under the person's control (Bandura, 1977; Bandura, Adams, Hardy, \& Howells, 1980; Dutton, 1993; Krueger \& Dickson, 1994; Swann, Chang-Schneider, \& Larsen McClarty, 2007). PBC also connects conceptually and empirically to attribution theory, which was already successfully applied to the study of new venture creation (Krueger et al., 2000; Zacharakis, Meyer, \& DeCastro, 1999). Ajzen (2002) argued that there is clear and consistent evidence for distinguishing between internal PBC (PSE) and external PBC (PCS). He also argued that there is sufficient commonality between self-efficacy (PSE) and controllability (PCS) to suggest a two-level hierarchical model for PBC. Thus, in Ajzen's (1991) TPB, $\mathrm{PBC}$ is the overarching, superordinate construct that is comprised of two lower-level components: PSE and PCS.

Drawing from Ajzen's (2002) rationale, Mair and Noboa (2006) and Hockerts (2017) used self-efficacy and perceived social support as proxies for PBC of the TPB. Selfefficacy is widely considered to be a key antecedent of entrepreneurial intention (Boyd \& Vozikis, 1994; Bullough, Renko, \& Myatt, 2014; Fitzsimmons \& Douglas, 2011; Kickul, Gundry, Barbosa, \& Whitcanack, 2009; Mcgee, Peterson, Mueller, \& Sequeira, 2009; Wilson, Kickul, \& Marlino, 2007; Zhao, Seibert, Hills, \& Seibert, 2005). Selfefficacy allows a person to perceive the creation of a social venture as a viable behaviour (Ip, Liang et al., 2018; Piperopoulos \& Dimov, 2015). Social support refers to the relationship that social entrepreneurs build with like-minded stakeholders in pursuit of the mission, e.g. social capital (Chan, 2016; Estrin, Mickiewicz, \& Stephan, 2013). Strong PSE and PCS regarding starting a new social business will generally lead to a strong intention to perform the behaviour. PSE and PCS would normally reflect the person's competencies and past experience as well as the anticipated support (or impediments) and assets (or obstacles) that the person may encounter (Ajzen, 1991; Chandler \& Jansen, 1992). Some researchers have found PBC to be the most important factor in shaping entrepreneurial intention (Arenius \& Kovalainen, 2006; Souitaris, Zerbinati, \& Al-Laham, 2007; van Gelderen et al., 2008). The authors expect similar relations between the combination of PSE and PCS, and the SEI of students. Thus, the authors formulate the following hypothesis:

H2: Perceived self-efficacy and perceived community support positively influence social entrepreneurial intention.

Social, cultural and environmental responsibility (SER) is a proxy for SSN in the TPB. SSN refers to the perceived social pressure to perform (or not to perform) the 
behaviour (compliance). Particularly, it is concerned with whether important reference people (family, friends, role models, etc.) approve or disapprove of the person's behaviour. It is also concerned with the extent that the opinion of reference people matters to the person (Ajzen, 1991, 2001). When the opinion of important reference people matters to the person, the intention to behave accordingly would be stronger if the opinion seems to encourage the behaviour (Cialdini \& Trost, 1998; Pruett et al., 2009). Results in the literature regarding the importance of SSN as an influencer of entrepreneurial intention have been inconsistent (Armitage \& Conner, 2001; Conner \& Armitage, 1998; Kautonen et al., 2013; Kolvereid \& Isaksen, 2006; Krueger et al., 2000; Lüthje \& Franke, 2003). Although, it has been shown to exert a strong influence on both ATP and PBC as it was originally alluded in Ajzen's (1991) TPB (Autio et al., 2001; Kautonen et al., 2013, 2015; Matthews \& Moser, 1996; Souitaris et al., 2007). Several authors have corroborated this argument from the point of view of social capital (Cooper, 1993; Liñán \& Santos, 2007; Matthews \& Moser, 1995; Scherer, Brodzinski, \& Wiebe, 1991). Personal moral values and standards have been identified as essential attributes of social entrepreneurs (Bornstein, 2005; Chell, Spence, Perrini, \& Harris, 2016; Hemingway, 2005; Koe Hwee Nga \& Shamuganathan, 2010; Yiu, Wan, Ng, Chen, \& Su, 2014). Moral beliefs have been found to be important factors of a person's behaviour (Kaiser, 2006; Rivis, Sheeran, \& Armitage, 2009). Therefore, social entrepreneurs often behave based on their sense of moral values. Mair and Noboa (2006) called this construct moral judgement and interpreted this sentiment through the lens of ethical principles that appeal to justice, human equality and respect for the dignity of the individual (Kohlberg, 1971). Hockerts (2017) on the other hand, called his construct moral obligation and argued that moral obligation can better measure the extent to which moral judgement will lead to moral intent. That is, moral judgement is a precursor of moral obligation which in turn is a precursor of moral intent (Haines, Street, \& Haines, 2008). The authors agree with Hockerts' (2017) rationale and extend the concept to encompass all sentiments of responsibility and stewardship towards social, cultural and environmental issues. Thus, the authors formulate the following hypotheses:

H3: Social, cultural and environmental responsibility positively influences social entrepreneurial intention.

H4: Social, cultural and environmental responsibility positively influences empathy towards others.

H5: Social, cultural and environmental responsibility positively influences perceived self-efficacy and perceived community support.

Experience with social issues was identified by Hockerts (2017) as a predictor of SEI. He argued that past experience such as family exposure (Carr \& Sequeira, 2007; Chlosta, Patzelt, Klein, \& Dormann, 2012) and work experience (Kautonen, Luoto, \& Tornikoski, 2010) have been already identified as one of the predictors of entrepreneurial intention. By the same token, prior experience such as participating in recycle programs, community service and knowledge of social issues have been recognised as predictors of prosocial behaviour-which is always preceded by prosocial intention 
(Ernst, 2011; Miralles, Giones, \& Riverola, 2016; Vining \& Ebreo, 1989). For the purpose of this study, the authors adopted the more general construct experience with social, cultural and environmental issues (ESI) as an indirect (distal) antecedent of the SEI of students by affecting the more direct (proximal) precursors of ETO (Batson, Early, \& Salvarani, 1997; Tukamushaba, Orobia, \& George, 2011), PSE and PCS (Gist \& Mitchell, 1992; Tierney \& Farmer, 2002; Zhao et al., 2005) and SER (Coff, 1999; Comunian \& Gielen, 1995; Thøgersen, 2002) which act as mediators between ESI and SEI. Thus, the authors formulate the following hypotheses:

H6: Experience with social, cultural and environmental issues positively influences empathy towards others.

H7: Experience with social, cultural and environmental issues positively influences social \& environmental responsibility.

H8: Experience with social, cultural and environmental issues positively influences perceived self-efficacy and perceived community support.

This systematic literature review focused on the influence of the university's ESS on ETO, PSE, PCS and SER. The university's ESS corresponds to contextual conditions-exogenous influences or more distal factors-that can affect, similar to ESI, the SEI of students indirectly via their influences on more proximal, motivational factors such as ETO, PSE, PCS and SER (Fishbein \& Ajzen, 2010). This argument is not new. In the past, several authors have conjectured that universities as stakeholders can be one of the most influential factors in encouraging new entrepreneurs (Bacq \& Alt, 2018; Debackere \& Veugelers, 2005; Di Gregorio \& Shane, 2003; Dyer, 2017; Henderson \& Robertson, 1999; Peterman \& Kennedy, 2003; Robinson, Huefner, \& Hunt, 1991; Shane, 2004; Souitaris et al., 2007; Trivedi, 2016; Zhao et al., 2005). Fewer authors have posited that environmental factors may have an influence on the SEI of students (Moorthy \& Annamalah, 2014; Politis et al., 2016; Salamzadeh et al., 2013). However, empirical studies linking external conditions for entrepreneurship and students' career choices also provided inconsistent results (Schwarz, Wdowiak, Almer-Jarz, \& Breitenecker, 2009). One explanation for this inconsistency could be that although structural conditions are similar for everyone living in the same context, e.g. the university's ESS are similar for students attending the same school; the perceptions, attitudes and behaviours might vary from student to student (Turker \& Selcuk, 2009). Nonetheless, it is reasonable to focus on the social entrepreneurial journey of students as an embedded process in the university context and thus, the university's ESS could provide an explanation of the relation between personal-related factors and SEI of students (Lüthje \& Franke, 2003; Schwarz et al., 2009).

Notwithstanding some of the comments above, there is also growing evidence that the university context has some influence on the entrepreneurial intention of students (Bae, Qian, Miao, \& Fiet, 2014; Bazan et al., 2019; Kraaijenbrink, Bos, \& Groen, 2010; Kraaijenbrink \& Wijnhoven, 2008; Liñán, Urbano, \& Guerrero, 2011; Sesen, 2013; Shirokova, Osiyevskyy, \& Bogatyreva, 2016; Trivedi, 2016; Turker \& Selcuk, 2009; Zhang, Duysters, \& Cloodt, 2014). The traditional way in which universities may affect the SEI of students is through the offering of social entrepreneurship education 
programs. The impact of social entrepreneurship education programs on the precursors of the SEI of students has been the subject of several studies in the past (Adelekan et al., 2018; Hockerts, 2017; Kedmenec et al., 2017; Kwong et al., 2012; Piperopoulos \& Dimov, 2015; Smith \& Woodworth, 2012; Tshikovhi \& Shambare, 2015). The investigation of other aspects of the university's ESS such as business incubation and spin-offs (Chiesa \& Piccaluga, 2000; Hughes, Ireland, \& Morgan, 2007; Markuerkiaga, Caiazza, Igartua, \& Errasti, 2016; Mian, 1996, 1997), technology transfer mechanisms (Bray \& Lee, 2000; Etzkowitz, 2003; Poole \& Robertson, 2003), university venture funds (Lerner, 2004) and mentoring and networking (Nielsen \& Lassen, 2012) are less common in the literature to date. This systematic literature review attempts to fill that gap by providing a mechanism for researchers to explore this phenomenon. It is clear that elements of the university's ESS are efficient ways of developing social entrepreneurial competencies of students and motivating them to consider a social entrepreneurial career (Franke \& Lüthje, 2004; Henderson \& Robertson, 1999; Kraaijenbrink et al., 2010; Peterman \& Kennedy, 2003). All the precursors of SEI would be affected by ESS, although SER, PSE and PCS seem a priori to be the ones that could be affected by the university's ESS the most (Shirokova et al., 2016). Furthermore, similarly to Trivedi's (2016) argument, the authors posit that the university's ESS is composed of three basic elements: entrepreneurial training (ET), start-up support (SS) and entrepreneurial milieu (EM). Thus, the authors formulate the following hypotheses:

H9: The university's environment and support system positively influences empathy towards others.

H10: The university's environment and support system positively influences social and environmental responsibility.

H11: The university's environment and support system positively influences perceived self-efficacy and perceived community support.

Table 4 summarizes the hypothesised connections among the constructs of the model. The arrows represent a direct, positive influence of one variable on another variable. A questionnaire operationalizing the proposed SEI model for students is shown in the Appendix.

Table 4 Proposed hypotheses

\begin{tabular}{ll}
\hline Hypothesis & Influence \\
\hline H1: ETO positively influences SEl. & ETO $\rightarrow$ SEl \\
H2: PSE and PCS positively influence SEl. & PBC $\rightarrow$ SEl \\
H3: SER positively influences SEl. & SER $\rightarrow$ SEl \\
H4: SER positively influences ETO. & SER $\rightarrow$ ETO \\
H5: SER positively influences PSE and PCS. & SER $\rightarrow$ PBC \\
H6: ESI positively influences ETO. & ESI $\rightarrow$ ETO \\
H7: ESI positively influences SER. & ESI $\rightarrow$ SER \\
H8: ESI positively influences PSE and PCS. & ESI $\rightarrow$ PBC \\
H9: ESS positively influences ETO. & ESS $\rightarrow$ ETO \\
H10: ESS positively influences SER. & ESS $\rightarrow$ SER \\
H11: ESS positively influences PSE and PCS. & ESS $\rightarrow$ PBC \\
\hline
\end{tabular}




\section{Conclusion}

It has been well documented in the literature that entrepreneurial behaviour is intentional and thus best predicted by the intention towards the behaviour, not by attitudes, beliefs, personality or demographics (Ajzen, 1991, 2001; Delmar \& Davidsson, 2000; Fayolle et al., 2006; Kolvereid, 1996b; Krueger et al., 2000; Krueger \& Carsrud, 1993). Researchers have proposed several models for understanding the entrepreneurial intention of students. Among those models are the Entrepreneurial Event Model (Shapero \& Sokol, 1982); the Entrepreneurial Support Model (Turker \& Selcuk, 2009); the Intentional Basic Model (Krueger \& Carsrud, 1993); the Lüthje \& Franke Model (Lüthje \& Franke, 2003); the Entrepreneurial Potential Model (Krueger \& Brazeal, 1994); the Individual Entrepreneurial Orientation Model (Langkamp Bolton \& Lane, 2012); the Davidsson Model (Davidsson, 1995); and the Entrepreneurial Intention-Constraint Model (Trivedi, 2017). Fewer models have been proposed for understanding the social entrepreneurial intention of students (Bacq \& Alt, 2018; Barton et al., 2018; Bloom \& Smith, 2010; Corner \& Ho, 2010; Hockerts, 2015, 2017; Ip, Liang, et al., 2018; Ip, Wu, et al., 2018; Kirby \& Ibrahim, 2011; Luc, 2018; Mair \& Noboa, 2006; Salamzadeh et al., 2013; Shahverdi et al., 2018). One goal of this study was to fill that gap in the literature and propose a methodology grounded in theory that can help universities to design their educational and other interventions aimed at encouraging more students to consider social entrepreneurship as a viable career choice after graduation.

Based on a systematic literature review and narrative synthesis of the antecedents of the SEI of post-secondary education students, the authors proposed a customized SEI model that modifies and extend the one proposed by Hockerts (2017). Hockerts (2017) based his model on Ajzen's (1991) TPB as proposed by Mair and Noboa (2006). According to the original TPB, in order to understand behaviour, e.g. starting a new venture, it is essential to understand intention. In turn, in order to understand intention, it is necessary to understand the precursors of intention, i.e. ATB, SSN and PBC (Bird, 1988; Katz \& Gartner, 1988; Krueger et al., 2000; Macmillan \& Katz, 1992). Two of the major strengths of the TPB are its applicability to a variety of behaviours and in a variety of contexts, and that an elicitation study forms the basis for developing questions to assess the theory's variables (Knabe, 2009). The TPB predicts that the more favourable the ATB and SSN, and the greater the PBC, the stronger the person's intention to perform the behaviour (Kolvereid, 1996b). In their model of SEI, Mair and Noboa (2006) replaced the three antecedents of intention, ATB, SSN and $\mathrm{PCB}$, with four equivalent precursors of intention: empathy with marginalized people, feeling of moral obligation, ability to effect change and perceived availability of support. Hockerts (2015) operationalised the said SEI model, i.e., the Social Entrepreneurial Antecedents Scale (SEAS), by developing and validating appropriate measures for the four constructs above and adding a fifth construct to account for prior experience with social problems. The SEAS has been the subject of reliability and validity analyses and applicability, and tested in an educational setting by its original author. The SEAS has shown evidence of being both theoretically sound and statistically robust instrument for assessing the SEI of students. This study provides a methodology to further validate those findings and adds an additional construct related to the university's entrepreneurial ecosystem. 


\section{Appendix}

\section{Questionnaire items}

Given the definition of a social enterprise as "an organization that pursues social, cultural, or environmental missions," students indicate their level of agreement with the below statements from 1 (total disagreement) to 7 (total agreement).

\section{Empathy towards others (ETO)}

ETO\# refers to the degree to which the person is able to intellectually recognise and emotionally share the feelings of others.

- ETO1-When thinking about disadvantaged people, I try to put myself in their shoes

- ETO2-Seeing disadvantaged people makes me want to help them

- ETO3-I feel compassion for marginalized people

\section{Social, cultural and environmental responsibility (SER)}

SER\# refers to the cognitive process that motivates a person to help others or the environment in pursuit of a mission.

- SER1-It is everybody's responsibility to help disadvantaged people

- SER2-Everybody has an obligation to help solve the problems that society faces

- SER3-Everybody needs to protect the environment for future generations

\section{Perceived self-efficacy (PSE)}

PSE\# refers to the perceived level of self-confidence to succeed in specific situations or perform a task.

- PSE1-I can make a contribution to address one of society's problems

- PSE2-I can figure out ways to help solve a problem that society faces

- PSE3-Everybody can contribute to solving the problems in society

\section{Perceived community support (PCS)}

PCS\# refers to trust and cooperation that can be derived from the person's network.

- PSS1-People will support me if I wanted to start a social enterprise

- PCS2-People will help me if I plan to address a problem in society

- PCS3-It is possible to attract funders for a new social enterprise

\section{Social entrepreneurial intention (SEI)}

SEI\# represents the intention of students to start a social venture.

- SEI1-I expect that in the future I will be involved in launching a social enterprise

- SEI2-My professional goal is to become a social entrepreneur

- SEI3-I am seriously thinking about starting a social enterprise in the future 
Experience with social, cultural and environmental issues (ESI)

ESI\# represents the familiarity of the person with social or environmental issues.

- ESI1-I have experience working on a problem faced by society

- ESI2-I have volunteered with a social enterprise in the past

- ESI3-I am familiar with the problems that society faces

University environment and support system (ESS)

ESS\# represents the entire entrepreneurial ecosystem in the university.

- ESS1 - The university provides a creative atmosphere to develop ideas for a social enterprise

- ESS2-The university creates awareness of social entrepreneurship as a possible career choice

- ESS3-The university provides networking opportunities for social entrepreneurial students

- ESS4-The university provides students with the knowledge needed to start a social enterprise

- ESS5-The university offers experiential learning related to social enterprise

- ESS6-The university arranges workshops and conferences on social entrepreneurship

- ESS7-The university has many resources to help students to start of a social enterprise

- ESS8-The university arranges mentoring services for social entrepreneurial students

- ESS9-The university provides students with ideas to start a new social enterprise

\section{Abbreviations}

ATB: Attitude towards the behaviour; EM: Entrepreneurial milieu; ESS: Environment and support system;

ET: Entrepreneurial training; ETO: Empathy towards others; PBC: Perceived behavioural control; PCS: Perceived community support; PSE: Perceived self-efficacy; SEAS: Social Entrepreneurial Antecedents Scale; SEl: Social entrepreneurial intention; SER: Social, cultural and environmental responsibility; SS: Start-up support; SSN: Suggestive social norm; TPB: Theory of planned behaviour

\section{Acknowledgements}

The corresponding author also acknowledges the additional support provided by the Office of the Vice-President (Research), the Office of the Dean of Engineering \& Applied Science, and the Office of the Dean of Business Administration at Memorial University.

\section{Authors' contributions}

CB identified the need for the review, specified the research questions and developed the review protocol; $H G, A S$ and $K G$ evaluated and piloted the review protocol and designed the study quality assessment; SF, AA, SY, CF, JR and NB conducted the search, selected the included documents and extracted the data. CB synthesized the information and wrote the manuscript. All authors read and approved the final manuscript.

Funding

The authors acknowledge the support from Atlantic Canada Opportunity Agency (ACOA), Newfoundland and Labrador's Department of Tourism, Culture, Industry and Innovation (TCII), the Memorial Centre for Entrepreneurship (MCE), and the Centre for Social Enterprise (CSE).

Availability of data and materials

The complete list of reviewed article is available upon request from the corresponding author.

Competing interests

The authors declare that they have no competing interests.

\section{Author details}

${ }^{1}$ Faculty of Engineering \& Applied Science and Memorial Centre for Entrepreneurship, Memorial University of Newfoundland, 240 Prince Phillips Drive, St. John's, NL A1B 3X5, Canada. ${ }^{2}$ Centre for Social Enterprise, Memorial 
University of Newfoundland, St. John's, Canada. ${ }^{3}$ Faculty of Science, Memorial University of Newfoundland, St. John's, Canada. ${ }^{4}$ Faculty of Engineering \& Applied Science, Memorial University of Newfoundland, St. John's, Canada.

Received: 23 May 2019 Accepted: 10 January 2020

Published online: 28 January 2020

\section{References}

Acedo, F. J., \& Casillas, J. C. (2005). Current paradigms in the international management field: An author co-citation analysis. International Business Review. https://doi.org/10.1016/j.ibusrev.2005.05.003.

Adelekan, S. A., Williamson, M., \& Atiku, S. O. (2018). Influence of social entrepreneurship pedagogical initiatives on students' attitudes and behaviours. Journal of Business \& Retail Management Research, 12(03). https://doi.org/10.24052/JBRMR/ V12IS03/ART-15.

Ajzen, I. (1987). Attitudes, traits, and actions: Dispositional prediction of behavior in personality and social psychology. Advances in Experimental Social Psychology, 20(C), 1-63. https://doi.org/10.1016/50065-2601(08)60411-6.

Ajzen, I. (1991). The theory of planned behavior. Organizational Behavior and Human Decision Processes, 50(2), 179-211. https://doi.org/10.1016/0749-5978(91)90020-T.

Ajzen, I. (2001). Nature and operation of attitudes. Annual Review of Psychology, 52(1), 27-58. https://doi.org/10.1146/annurev. psych.52.1.27.

Ajzen, I. (2002). Perceived behavioral control, self-efficacy, locus of control, and the theory of planned behavior. Journal of Applied Social Psychology. https://doi.org/10.1111/j.1559-1816.2002.tb00236.x.

Ajzen, I., \& Fishbein, M. (2004). Questions raised by a reasoned action approach: Comment on Ogden (2003). Health Psychology, 23(4), 431-434. https://doi.org/10.1037/0278-6133.23.4.431.

Arenius, P., \& Kovalainen, A. (2006). Similarities and differences across the factors associated with women's self-employment preference in the Nordic countries. International Small Business Journal, 24(1), 31-59. https://doi.org/10.1177/ 0266242606059778.

Armitage, C. J., \& Conner, M. (2001). Efficacy of the theory of planned behaviour: A meta-analytic review. British Journal of Social Psychology, 40(4), 471-499. https://doi.org/10.1348/014466601164939.

Ashour, S. (2016). Social and business entrepreneurship as career options for university students in the United Arab Emirates: The drive-preparedness gap. Cogent Education. https://doi.org/10.1080/2331186X.2016.1234425.

Aure, P. A. H. (2018). Exploring the social entrepreneurial intentions of senior high school and college students in a Philippine University: A PLS-SEM approach. Journal of Legal, Ethical and Regulatory Issues, 21(2), 1-11.

Austin, J., Stevenson, H., \& Wei-Skillern, J. (2006). Social and commercial entrepreneurship: Same, different, or both? Entrepreneurship Theory and Practice, 30(1), 1-22. https://doi.org/10.1111/j.1540-6520.2006.00107.x.

Autio, E., Keeley, R. H., Klofsten, M., Parker, G. G. C., \& Hay, M. (2001). Entrepreneurial intent among students in Scandinavia and in the USA. Enterprise and Innovation Management Studies, 2(2), 145-160. https://doi.org/10.1080/ 14632440110094632.

Bacq, S., \& Alt, E. (2018). Feeling capable and valued: A prosocial perspective on the link between empathy and social entrepreneurial intentions. Journal of Business Venturing. https://doi.org/10.1016/j.jbusvent.2018.01.004.

Bae, T. J., Qian, S. Miao, C., \& Fiet, J. O. (2014). The relationship between entrepreneurship education and entrepreneurial intentions: A meta-analytic review. Entrepreneurship: Theory and Practice, 38(2), 217-254. https://doi.org/10.1111/etap. 12095.

Bandura, A. (1977). Self-efficacy: Toward a unifying theory of behavioral change. Psychological Review, 84(2), 191-215. https:// doi.org/10.1037/0033-295x.84.2.191.

Bandura, A., Adams, N. E., Hardy, A. B., \& Howells, G. N. (1980). Tests of the generality of self-efficacy theory. Cognitive Therapy and Research, 4(1), 39-66. https://doi.org/10.1007/BF01173354.

Barton, M., Schaefer, R., \& Canavati, S. (2018). To be or not to be a social entrepreneur: Motivational drivers amongst American business students. Entrepreneurial Business and Economics Review. https://doi.org/10.15678/EBER.2018.060101.

Batson, C. D., Early, S., \& Salvarani, G. (1997). Perspective taking: Imagining how another feels versus imagining how you would feel. Personality and Social Psychology Bulletin. https://doi.org/10.1177/0146167297237008.

Bazan, C., Shaikh, A., Frederick, S., Amjad, A., Yap, S., Finn, C., \& Rayner, J. (2019). Effect of Memorial University's Environment \& Support System in shaping entrepreneurial intention of students. Journal of Entrepreneurship Education, 22(1), 1-35.

Bird, B. (1988). Implementing entrepreneurial ideas: The case for intention. Academy of Management Review, 13(3), 442-453. https://doi.org/10.5465/AMR.1988.4306970.

Bloom, P. N., \& Smith, B. R. (2010). Identifying the drivers of social entrepreneurial impact: Theoretical development and an exploratory empirical test of SCALERS. Journal of Social Entrepreneurship, 1(1), 126-145. https://doi.org/10.1080/ 19420670903458042.

Borman, W. C., Penner, L. A., Allen, T. D., \& Motowidlo, S. J. (2001). Personality predictors of citizenship performance. International Journal of Selection and Assessment. https://doi.org/10.1111/1468-2389.00163.

Bornstein, D. (2005). The price of a dream: The story of the Grameen Bank, Oxford University Press, New York.

Boyd, N. G., \& Vozikis, G. S. (1994). The influence of self-efficacy on the development of entrepreneurial intentions and actions. Entrepreneurship Theory and Practice, 18, 63-77. https://doi.org/10.1177/104225879401800404.

Bray, M. J., \& Lee, J. N. (2000). University revenues from technology transfer: Licensing fees vs. equity positions. Journal of Business Venturing, 15(5-6), 385-392. https://doi.org/10.1016/S0883-9026(98)00034-2.

Bullough, A., Renko, M., \& Myatt, T. (2014). Danger zone entrepreneurs: The importance of resilience and self-efficacy for entrepreneurial intentions. Entrepreneurship: Theory and Practice. https://doi.org/10.1111/etap.12006.

Carr, J. C., \& Sequeira, J. M. (2007). Prior family business exposure as intergenerational influence and entrepreneurial intent: A theory of planned behavior approach. Journal of Business Research. https://doi.org/10.1016/j.jbusres.2006.12.016.

Casillas, J. C., \& Acedo, F. J. (2007). Evolution of the intellectual structure of family business literature: A bibliometric study of FBR. Family Business Review, 20(2), 141-162. https://doi.org/10.1111/j.1741-6248.2007.00092.x.

Chan, A. (2016). Personal wellbeing of participants of social purpose enterprises: The influence of social support. Voluntas. https://doi.org/10.1007/s11266-015-9637-4. 
Chandler, G. N., \& Jansen, E. (1992). The founder's self-assessed competence and venture performance. Journal of Business Venturing, 7(3), 223-236. https://doi.org/10.1016/0883-9026(92)90028-P.

Chell, E., Spence, L. J., Perrini, F., \& Harris, J. D. (2016). Social entrepreneurship and business ethics: Does social equal ethical? Journal of Business Ethics. https://doi.org/10.1007/s10551-014-2439-6.

Chen, C. C., Greene, P. G., \& Crick, A. (1998). Does entrepreneurial self-efficacy distinguish entrepreneurs from managers? Journal of Business Venturing. https://doi.org/10.1016/S0883-9026(97)00029-3.

Chia, C.-C., \& Liang, C. (2016). Influence of creativity and social capital on entrepreneurial intention of tourism students. Journal of Entrepreneurship, Management and Innovation, 2, 151-168.

Chiesa, V., \& Piccaluga, A. (2000). Exploitation and diffusion of public research: The case of academic spin-off companies in Italy. R\&D Management, 30(4), 329-340. https://doi.org/10.1111/1467-9310.00187.

Chipeta, E. M., \& Surujlal, J. (2017). Influence of attitude, risk taking propensity and proactive personality on social entrepreneurship intentions. Polish Journal of Management Studies. https://doi.org/10.17512/pjms.2017.15.2.03.

Chlosta, S., Patzelt, H., Klein, S. B., \& Dormann, C. (2012). Parental role models and the decision to become self-employed: The moderating effect of personality. Small Business Economics. https://doi.org/10.1007/s11187-010-9270-y.

Cialdini, R., \& Trost, M. (1998). Social influence: Social norms, conformity and compliance. In The Handbook of Social Psychology (Vol. 2). https://doi.org/10.2307/2654253.

Coff, R. W. (1999). When competitive advantage doesn't lead to performance: The resource-based view and stakeholder bargaining power. Organization Science. https://doi.org/10.1287/orsc.10.2.119.

Comunian, A. L., \& Gielen, U. P. (1995). Moral reasoning and prosocial action in Italian culture. Journal of Social Psychology. https://doi.org/10.1080/00224545.1995.9713973.

Conner, M., \& Armitage, C. J. (1998). Extending the theory of planned behavior: A review and avenues for further research. Journal of Applied Social Psychology, 28(15), 1429-1464. https://doi.org/10.1111/j.1559-1816.1998.tb01685.x.

Cooper, A. C. (1993). Challenges in predicting new firm performance. Journal of Business Venturing, 8(3), 241-253. https://doi. org/10.1016/0883-9026(93)90030-9.

Corner, P. D., \& Ho, M. (2010). How opportunities develop in social entrepreneurship. Entrepreneurship: Theory and Practice, 34(4), 635-659. https://doi.org/10.1111/j.1540-6520.2010.00382.x.

Davidsson, P. (1991). Continued entrepreneurship: Ability, need, and opportunity as determinants of small firm growth. Journal of Business Venturing, 6(6), 405-429. https://doi.org/10.1016/0883-9026(91)90028-C.

Davidsson, P. (1995). Determinants of entrepreneurial intentions. In RENT IX Workshop. Piacenza: Retrieved from https:// eprints.qut.edu.au/2076/1/RENT_IX.pdf.

Debackere, K., \& Veugelers, R. (2005). The role of academic technology transfer organizations in improving industry science links. Research Policy, 34(3), 321-342. https://doi.org/10.1016/j.respol.2004.12.003.

Dees, J. G. (2012). A tale of two cultures: Charity, problem solving, and the future of social entrepreneurship. Journal of Business Ethics. https://doi.org/10.1007/s10551-012-1412-5.

Delmar, F., \& Davidsson, P. (2000). Where do they come from? Prevalence and characteristics of nascent entrepreneurs. Entrepreneurship and Regional Development, 12(1), 1-23. https://doi.org/10.1080/089856200283063.

Devonish, D., Alleyne, P., Charles-Soverall, W., Young Marshall, A., \& Pounder, P. (2010). Explaining entrepreneurial intentions in the Caribbean. International Journal of Entrepreneurial Behavior \& Research, 16(2), 149-171. https://doi.org/10.1108/ 13552551011027020.

Di Gregorio, D., \& Shane, S. (2003). Why do some universities generate more start-ups than others? In Research Policy (Vol. 32, pp. 209-227). https://doi.org/10.1016/50048-7333(02)00097-5.

Dutton, J. E. (1993). The making of organizational opportunities: An interpretative pathway to organizational change. Research in Organizaional Behavior, 15, 195-226.

Dyer, W. G., Jr. (2017). Toward a Theory of Entrepreneurial Careers. https://doi.org/10.1177/104225879501900202.

Ernst, K. (2011). Heart over mind_-An empirical analysis of social entrepreneurial intention formation on the basis of the theory of planned behaviour. University Wuppertal. https://doi.org/10.1111/j.1365-2761.1989.tb00281.x.

Estrin, S., Mickiewicz, T., \& Stephan, U. (2013). Entrepreneurship, social capital, and institutions: Social and commercial entrepreneurship across nations. Entrepreneurship: Theory and Practice. https://doi.org/10.1111/etap.12019.

Etzkowitz, H. (2003). Research groups as 'quasi- firms': The invention of the entrepreneurial university. Research Policy, 32(1), 109-121.

Fayolle, A., Gailly, B. B., Lassas-Clerc, N., \& Lassas-Clerc, N. (2006). Assessing the impact of entrepreneurship education programmes: A new methodology. Journal of European Industrial Training, 30(9), 701-720. https://doi.org/10.1108/ 03090590610715022.

Fishbein, M., \& Ajzen, I. (1975). Belief, attitude, intention and behaviour: An introduction to theory and research. Reading, Addison Wesley, (August), 480. doi: https://doi.org/10.2307/2065853.

Fishbein, M., \& Ajzen, I. (2010). Predicting and changing behaviour: The reasoned action approach. New York: Psychology Press. https://doi.org/10.4324/9780203937082.

Fitzsimmons, J. R.., \& Douglas, E. J. (2011). Interaction between feasibility and desirability in the formation of entrepreneurial intentions. Journal of Business Venturing. https://doi.org/10.1016/j.jbusvent.2010.01.001.

Forbes, A., \& Griffiths, P. (2002). Methodological strategies for the identification and synthesis of "evidence" to support decision-making in relation to complex healthcare systems and practices. Nursing Inquiry, 9(3), 141-155. https://doi.org/ 10.1046/j.1440-1800.2002.00146.x.

Franke, N., \& Lüthje, C. (2004). Entrepreneurial intentions of business students-A benchmarking study. International Journal of Innovation and and Technology Management, 1(3), 269-288. https://doi.org/10.1007/s10551-011-0925-7.

Fulop, N. (2001). Studying the organisation and delivery of health services: Research methods. Routledge Retrieved from https:// books.google.ca/books/about/Studying_the_Organisation_and_Delivery_o.html?id=TqE43mtOFtgC\&redir_esc=y.

Gist, M. E., \& Mitchell, T. B. (1992). Self-efficacy: A theoretical analysis of its determinants and malleability. Academy of Management Review. https://doi.org/10.5465/AMR.1992.4279530.

Goetz, J. L., Keltner, D., \& Simon-Thomas, E. (2010). Compassion: An evolutionary analysis and empirical review. Psychological Bulletin. https://doi.org/10.1037/a0018807.

Haines, R., Street, M. D., \& Haines, D. (2008). The influence of perceived importance of an ethical issue on moral judgment, moral obligation, and moral intent. Journal of Business Ethics. https://doi.org/10.1007/s10551-007-9502-5. 
Harris, M. L., \& Gibson, S. G. (2008). Examining the entrepreneurial attitudes of US business students. Education + Training, 50(7), 568-581. https://doi.org/10.1108/00400910810909036.

Hemingway, C. A. (2005). Personal values as a catalyst for corporate social entrepreneurship. Journal of Business Ethics. https:// doi.org/10.1007/s10551-005-0132-5.

Henderson, R., \& Robertson, M. (1999). Who wants to be an entrepreneur? Young adult attitudes to entrepreneurship as a career. Education + Training, 41(5), 236-245. https://doi.org/10.1108/00400919910279973.

Hockerts, K. (2015). The social entrepreneurial antecedents scale (SEAS): A validation study. Social Enterprise Journal. https:// doi.org/10.1108/SEJ-05-2014-0026.

Hockerts, K. (2017). Determinants of social entrepreneurial intentions. Entrepreneurship: Theory and Practice. https://doi.org/10. 1111/etap.12171.

Hughes, M., Ireland, R. D., \& Morgan, R. E. (2007). Stimulating dynamic value: Social capital and business incubation as a pathway to competitive success. Long Range Planning, 40(2), 154-177. https://doi.org/10.1016/j.lrp.2007.03.008.

Huster, K., Petrillo, C., O'Malley, G., Glassman, D., Rush, J., \& Wasserheit, J. (2017). Global social entrepreneurship competitions: Incubators for innovations in Global Health? Journal of Management Education. https://doi.org/10.1177/1052562916669965.

lakovleva, T., Kolvereid, L., \& Stephan, U. (2011). Entrepreneurial intentions in developing and developed countries. Education and Training, 53(5), 353-370. https://doi.org/10.1108/00400911111147686.

Ip, C. Y., Liang, C., Wu, S. C., Law, K. M. Y., \& Liu, H. C. (2018). Enhancing social entrepreneurial intentions through entrepreneurial creativity: A Comparative Study Between Taiwan and Hong Kong. Creativity Research Journal. https://doi. org/10.1080/10400419.2018.1446744

Ip, C. Y., Wu, S. C., Liu, H. C., \& Liang, C. (2018). Social entrepreneurial intentions of students from Hong Kong. Journal of Entrepreneurship. https://doi.org/10.1177/0971355717738596.

Jensen, L. A., \& Allen, M. N. (1996). Meta-synthesis of qualitative findings. Qualitative Health Research, 6(4), 553-560. https://doi. org/10.1177/104973239600600407.

Jones, K. (2004). Mission drift in qualitative research, or moving toward a systematic review of qualitative studies, moving back to a more systematic narrative review. The Qualitative Report, 9(1), 95-112. https://doi.org/10.1207/ s15327000em0504_4.

Jones, M., Coviello, N., \& Tang, Y. (2011). International entrepreneurship research (1989-2009): A domain ontology and thematic analysis. Journal of Business Venturing, 26(6), 632-659. https://doi.org/10.1016/j.jbusvent.2011.04.001.

Kaiser, F. G. (2006). A moral extension of the theory of planned behavior: Norms and anticipated feelings of regret in conservationism. Personality and Individual Differences. https://doi.org/10.1016/j.paid.2005.11.028.

Katz, J. (1994). Modelling entrepreneurial career progressions: Concepts and considerations. Entrepreneurship: Theory and Practice, 19(2), 23-40 Retrieved from http://go.galegroup.com/ps/i.do?id=GALE\%7CA18259840\&sid=googleScholar\&v=2.1 \&it=r\&linkaccess=fulltext\&issn=10422587\&p=AONE\&s $W=W$.

Katz, J., \& Gartner, W. (1988). Properties of emerging organizations. Academy of Management Review, 13(3), 429-441. https:// doi.org/10.5465/AMR.1988.4306967.

Kautonen, T., Luoto, S., \& Tornikoski, E. T. (2010). Influence of work history on entrepreneurial intentions in 'prime age' and 'third age': A preliminary study. International Small Business Journal. https://doi.org/10.1016/0002-9149(94)90358-1.

Kautonen, T., van Gelderen, M., \& Fink, M. (2015). Robustness of the theory of planned behavior in predicting entrepreneurial intentions and actions. Entrepreneurship: Theory and Practice, 39(3), 655-674. https://doi.org/10.1111/etap.12056.

Kautonen, T., van Gelderen, M., \& Tornikoski, E. T. (2013). Predicting entrepreneurial behaviour: A test of the theory of planned behaviour. Applied Economics, 45(6), 697-707. https://doi.org/10.1080/00036846.2011.610750.

Kedmenec, I., Rebernik, M., \& Tominc, P. (2017). Social entrepreneurship education and its association with perceived desirability and feasibility of social entrepreneurship among business students. Croatian Journal of Education, 18(4), 10351065. https://doi.org/10.15516/cje.v18i4.1774.

Khanin, D. (2011). Market failures and the strategies of social entrepreneurship. Academy of Management Proceedings, 2011(1), 1-6. https://doi.org/10.5465/AMBPP.2011.65869498.

Kickul, J., Gundry, L. K., Barbosa, S. D., \& Whitcanack, L. (2009). Intuition versus analysis? Testing differential models of cognitive style on entrepreneurial self-efficacy and the new venture creation process. Entrepreneurship: Theory and Practice. https:// doi.org/10.1111/j.1540-6520.2009.00298.x.

Kim, M.-S., \& Hunter, J. E. (1993). Relationships among attitudes, behavioral intentions, and behavior: A meta-analysis of past research, part 2. Communication Research, 20(3), 331-364. https://doi.org/10.1177/009365093020003001.

Kirby, D. A., \& Ibrahim, N. (2011). The case for (social) entrepreneurship education in Egyptian universities. Education and Training. https://doi.org/10.1108/00400911111147712.

Knabe, A. (2009). Applying Ajzen's theory of planned behavior to a study of online course adoption in public relations education. Faculty of the Graduate School. https://doi.org/10.1080/08874417.2016.1222891.

Koe Hwee Nga, J., \& Shamuganathan, G. (2010). The influence of personality traits and demographic factors on social entrepreneurship start up intentions. Journal of Business Ethics. https://doi.org/10.1007/s10551-009-0358-8.

Kohlberg, L. (1971). The philosophy of moral development moral stages and the idea of justice. In Moral Education.

Kolvereid, L. (1996a). Organizational employment versus self-employment: Reasons for career choice intentions. Entrepreneurship Theory and Practice, 21(1), 23-31. https://doi.org/10.6018/analesps.31.1.161461.

Kolvereid, L. (1996b). Prediction of employment status choice intentions. Entrepreneurship: Theory and Practice Retrieved from http://www.questia.com/PM.qst?a=o\&amp;se=gglsc\&amp;d=5002278812\%5Cn http://web.ebscohost.com/ehost/ pdfviewer/pdfviewer?sid=520195f2-f364-4fe8-afa6-c2e9016bfa2c@sessionmgr111\&vid=5\&hid=118.

Kolvereid, L., \& Isaksen, E. (2006). New business start-up and subsequent entry into self-employment. Journal of Business Venturing, 21(6), 866-885. https://doi.org/10.1016/j.jbusvent.2005.06.008.

Konakll, T. (2015). Effects of self-efficacy on social entrepreneurship in education: A Correlational Research. Research in Education. https://doi.org/10.7227/RIE.0019.

Kraaijenbrink, J., Bos, G., \& Groen, A. (2010). What do students think of the entrepreneurial support given by their universities? International Journal of Entrepreneurship and Small Business, 9(1), 110. https://doi.org/10.1504/JESB.2010.029512.

Kraaijenbrink, J., \& Wijnhoven, F. (2008). Managing heterogeneous knowledge: A theory of external knowledge integration. Knowledge Management Research and Practice, 6(4), 274-286. https://doi.org/10.1057/kmrp.2008.26. 
Krueger, N. (2005). Sustainable entrepreneurship: Broadening the definition of opportunity. In USASBE Conference, Las Vegas, NE (p. 208) Retrieved from http://scholar.google.com/scholar?hl=en\&btnG=Search\&q=intitle:Sustainable+ Entrepreneurship+:+Broadening+the+Definition+of+?+Opportunity+?\#0.

Krueger, N., \& Brazeal, D. (1994). Entrepreneurial Potential and Potential Entrepreneurs. Entrepreneurship Theory and Practice, 91-104. https://doi.org/10.2139/ssrn.1505244.

Krueger, N., \& Carsrud, A. (1993). Entrepreneurial intentions: Applying the theory of planned behaviour. Entrepreneurship \& Regional Development, 5(4), 315-330. https://doi.org/10.1080/08985629300000020.

Krueger, N., \& Dickson, P. (1994). How believing in ourselves increases risk taking: Perceived self-efficacy and opportunity recognition. Decision Sciences, 25(3), 385-400. https://doi.org/10.1111/j.1540-5915.1994.tb00810.x.

Krueger, N., Reilly, M., \& Carsrud, A. (2000). Competing models of entrepreneurial intentions. Journal of Business Venturing, 15(5), 411-432. https://doi.org/10.1016/S0883-9026(98)00033-0.

Kwong, C. C. Y., Thompson, P., \& Cheung, C. W. M. (2012). The effectiveness of social business plan competitions in developing social and civic awareness and participation. Academy of Management Learning and Education. https://doi. org/10.5465/amle.2011.0007A.

Lacap, J. P. G., Mulyaningsih, H. D., \& Ramadani, V. (2018). The mediating effects of social entrepreneurial antecedents on the relationship between prior experience and social entrepreneurial intent. Journal of Science and Technology Policy Management, 9(3), 329-346. https://doi.org/10.1108/JSTPM-03-2018-0028.

Langkamp Bolton, D., \& Lane, M. D. (2012). Individual entrepreneurial orientation: Development of a measurement instrument. Education + Training, 54(2/3), 219-233. https://doi.org/10.1108/00400911211210314.

Lee, S. H., \& Wong, P. K. (2004). An exploratory study of technopreneurial intentions: A career anchor perspective. Journal of Business Venturing, 19(1), 7-28. https://doi.org/10.1016/S0883-9026(02)00112-X.

Lent, R. W., Brown, S. D., \& Hackett, G. (1994). Toward a unifying social cognitive theory of career and academic interest, choice, and performance. Journal of Vocational Behavior, 45(1), 79-122. https://doi.org/10.1006/jvbe.1994.1027.

Lerner, J. (2004). The University and the start-up: Lessons from the past two decades. The Journal of Technology Transfer, 30(1), 49-56. https://doi.org/10.1007/s10961-004-4357-8.

Liang, C., Ip, C. Y., Wu, S. C., Law, K. M. Y., Wang, J. H., Peng, L. P., \& Liu, H. C. (2017). Personality traits, social capital, and entrepreneurial creativity: Comparing green socioentrepreneurial intentions across Taiwan and Hong Kong. Studies in Higher Education. https://doi.org/10.1080/03075079.2017.1418310.

Liñán, F. (2004). Intention-based models of entrepreneurship education. Piccolla Impresa/Small Business, 3(January 2004), 1-30.

Liñán, F., \& Chen, Y. (2006). Testing the entrepreneurial intention model on a two-country sample. Documents de Treball, 06(7), 1-37.

Liñán, F., \& Chen, Y. W. (2009). Development and cross-cultural application of a specific instrument to measure entrepreneurial intentions. Entrepreneurship: Theory and Practice, 33(3), 593-617. https:/doi.org/10.1111/j.1540-6520.2009.00318.x.

Liñán, F., \& Fayolle, A. (2015). A systematic literature review on entrepreneurial intentions: Citation, thematic analyses, and research agenda. International Entrepreneurship and Management Journal, 11(4), 907-933. https://doi.org/10.1007/s11365015-0356-5.

Liñán, F., \& Santos, F. F. J. (2007). Does social capital affect entrepreneurial intentions? International Advances in Economic Research, 13(4), 443-453. https://doi.org/10.1007/s11294-007-9109-8.

Liñán, F., Urbano, D., \& Guerrero, M. (2011). Regional variations in entrepreneurial cognitions: Start-up intentions of university students in Spain. Entrepreneurship and Regional Development, 23(3-4), 187-215. https://doi.org/10.1080/ 08985620903233929.

London, M. (2010). Understanding social advocacy: An integrative model of motivation, strategy, and persistence in support of corporate social responsibility and social entrepreneurship. Journal of Management Development. https://doi.org/10. 1108/02621711011025768.

Long, D. R., Strauss, A., \& Corbin, J. (2006). Basics of qualitative research: Grounded Theory Procedures and Techniques. The Modern Language Journal. https://doi.org/10.2307/328955.

Luc, P. T. (2018). The relationship between perceived access to finance and social entrepreneurship intentions among university students in Vietnam. The Journal of Asian Finance, Economics and Business, 5(1), 63-72. https://doi.org/10.13106/ jafeb.2018.vol5.no1.63.

Lüthje, C., \& Franke, N. (2003). The 'making' of an entrepreneur: Testing a model of entrepreneurial intent among engineering students at MIT. R\&D Management, 33(2), 135-147. https://doi.org/10.1111/1467-9310.00288.

Macmillan, I., \& Katz, J. (1992). Idiosyncratic milieus of entrepreneurial research: The need for comprehensive theories. Journal of Business Venturing, 7, 1-8. https://doi.org/10.1016/0883-9026(92)90031-L.

Mair, J., \& Noboa, E. (2006). Social entrepreneurship: How intentions to create a social venture are formed. Social Entrepreneurship. https://doi.org/10.1057/9780230625655.

Markuerkiaga, L., Caiazza, R., Igartua, J. I., \& Errasti, N. (2016). Factors fostering students' spin-off firm formation. Journal of Management Development, 35(6), 814-846. https://doi.org/10.1108/JMD-03-2016-0034

Matthews, C. H., \& Moser, S. B. (1995). Family background and gender: Implications for interest in small firm ownership. Entrepreneurship and Regional Development, 7(4), 365-377. https://doi.org/10.1080/08985629500000023.

Matthews, C. H., \& Moser, S. B. (1996). A longitudinal investigation of the impact of family background and gender on interest in small firm ownership. Journal of Small Business Management, 34(2), 29 https://doi.org/Article.

Mcgee, J. E., Peterson, M., Mueller, S. L., \& Sequeira, J. M. (2009). Entrepreneurial self-efficacy: Refining the measure. Entrepreneurship: Theory and Practice. https://doi.org/10.1111/j.1540-6520.2009.00304.X.

Mehrabian, A., \& Epstein, N. (1972). A measure of emotional empathy. Journal of Personality. https://doi.org/10.1111/j.14676494.1972.tb00078.x

Mian, S. (1997). Assessing and managing the university technology business incubator: An integrative framework. Journal of Business Venturing, 12(4), 251-285. https://doi.org/10.1016/S0883-9026(96)00063-8.

Mian, S. A. (1996). Assessing value-added contributions of university technology business incubators to tenant firms. Research Policy, 25(3), 325-335. https://doi.org/10.1016/0048-7333(95)00828-4.

Miller, T. L., Grimes, M. G., Mcmullen, J. S., \& Vogus, T. J. (2012). Venturing for others with heart and head: How compassion encourages social entrepreneurship. Academy of Management Review. https://doi.org/10.5465/amr.2010.0456. 
Miralles, F., Giones, F., \& Riverola, C. (2016). Evaluating the impact of prior experience in entrepreneurial intention. International Entrepreneurship and Management Journal. https://doi.org/10.1007/s11365-015-0365-4.

Moorthy, R., \& Annamalah, S. (2014). Consumers' perceptions towards motivational intentions of social entrepreneurs in Malaysia. Integrative Business and Economics Research, 3(1), 257-287.

Moriano, J. A., Gorgievski, M., Laguna, M., Stephan, U., \& Zarafshani, K. (2012). A cross-cultural approach to understanding entrepreneurial intention. Journal of Career Development. https://doi.org/10.1177/0894845310384481.

Nielsen, S. L., \& Lassen, A. H. (2012). Identity in entrepreneurship effectuation theory: A supplementary framework. International Entrepreneurship and Management Journal, 8(3), 373-389. https://doi.org/10.1007/s11365-011-0180-5.

Oswald, P. A. (1996). The effects of cognitive and affective perspective taking on empathic concern and altruistic helping. Journal of Social Psychology. https://doi.org/10.1080/00224545.1996.9714045.

Othman, N., \& Ab Wahid, H. (2014). Social entrepreneurship among participants in the students in free enterprise program. Education and Training. https://doi.org/10.1108/ET-09-2013-0111.

Peterman, N. E., \& Kennedy, J. (2003). Enterprise education: Influencing students' perceptions of entrepreneurship. Entrepreneurship Theory and Practice, 28(2), 129-144. https://doi.org/10.1046/.1540-6520.2003.00035.x.

Piperopoulos, P., \& Dimov, D. (2015). Burst bubbles or build steam? Entrepreneurship education, entrepreneurial self-efficacy, and entrepreneurial intentions. Journal of Small Business Management. https://doi.org/10.1111/jsbm.12116.

Politis, K., Ketikidis, P., Diamantidis, A. D., \& Lazuras, L. (2016). An investigation of social entrepreneurial intentions formation among south-east European postgraduate students. Journal of Small Business and Enterprise Development. https://doi.org/ 10.1108/JSBED-03-2016-0047.

Poole, D., \& Robertson, B. (2003). Hunting the snark or leading with purpose? Managing the enterprise university. Journal of Management and Organization, 9(3), 8-24. https://doi.org/10.5172/jmo.2003.9.3.8.

Popay, J., Roberts, H., Sowden, A., \& Petticrew, M. (2006). Narrative synthesis in systematic reviews: A product from the ESRC methods Programme. ESRC Methods Programme, 2006, 93. https://doi.org/10.13140/2.1.1018.4643.

Preston, S. D., Bechara, A., Damasio, H., Grabowski, T. J., Stansfield, R. B., Mehta, S., \& Damasio, A. R. (2007). The neural substrates of cognitive empathy. Social Neuroscience. https://doi.org/10.1080/17470910701376902.

Prieto, L. C. (2011). The influence of proactive personality on social entrepreneurial intentions among African-American and hispanic undergraduate students: The moderating role of hope. Academy of Entrepreneurship Journal.

Prieto, L. C., Phipps, S. T. A., \& Friedrich, T. L. (2012). Social entrepreneur development: An integration of critical pedagogy, the theory of planned behavior and the ACS model. Academy of Entrepreneurship Journal. https://doi.org/10.1108/17506200710779521.

Pruett, M., Shinnar, R., Toney, B., Llopis, F., \& Fox, J. (2009). Explaining entrepreneurial intentions of university students: A crosscultural study. International Journal of Entrepreneurial Behavior \& Research, 15(6), 571-594. https://doi.org/10.1108/ 13552550910995443.

Radin, R. S. A., Rahman, A., Othman, N., \& Pihie, Z. A. L. (2017). Social entrepreneurial intention among students of different status and university category. International Journal of Economic Research, 14(15), 377-394.

Rivis, A., Sheeran, P., \& Armitage, C. J. (2009). Expanding the affective and normative components of the theory of planned behavior: A meta-analysis of anticipated affect and moral norms. Journal of Applied Social Psychology. https://doi.org/10. 1111/j.1559-1816.2009.00558.x.

Robinson, P. B., Stimpson, D. V, Huefner, J. C., \& Hunt, H. K. (1991). An attitude approach to the prediction of entrepreneurship. Entrepreneurship Theory and Practice 15, 13-31.

Salamzadeh, A., Azimi, M. A., \& Kirby, D. A. (2013). Social entrepreneurship education in higher education: Insights from a developing country. International Journal of Entrepreneurship and Small Business. https:/doi.org/10.1504/JESB.2013.055691.

Scherer, R. F., Brodzinski, J. D., \& Wiebe, F. A. (1991). Examining the relationship between personality and entrepreneurial career preference. Entrepreneurship and Regional Development, 3(2), 195-206. https://doi.org/10.1080/08985629100000013.

Schwarz, E. J., Wdowiak, M. A., Almer-Jarz, D. A., \& Breitenecker, R. J. (2009). The effects of attitudes and perceived environment conditions on students' entrepreneurial intent. Education + Training, 51(4), 272-291. https://doi.org/10.1108/ 00400910910964566.

Seelos, C., \& Mair, J. (2005). Social entrepreneurship—-the contribution of individual entrepreneurs to sustainable development. SSRN. https://doi.org/10.2139/ssrn.701181.

Segal, G., Borgia, D., \& Schoenfeld, J. (2005). The motivation to become an entrepreneur. International Journal of Entrepreneurial Behavior \& Research, 11(1), 42-57. https://doi.org/10.1108/13552550510580834.

Sesen, H. (2013). Personality or environment? A comprehensive study on the entrepreneurial intentions of university students. Education and Training, 55(7), 624-640. https://doi.org/10.1108/ET-05-2012-0059.

Sezen-Gultekin, G., \& Gur-Erdogan, D. (2016). The relationship and effect between lifelong learning tendencies and social entrepreneurship characteristics of prospective teachers. Anthropologist. https://doi.org/10.1080/09720073.2016.11891996.

Shahverdi, M., Ismail, K., \& Qureshi, M. I. (2018). The effect of perceived barriers on social entrepreneurship intention in Malaysian universities: The moderating role of education. Management Science Letters, 8(5), 341-352. https://doi.org/10. 5267/j.msl.2018.4.014.

Shane, S. (2004). Academic entrepreneurship: University spinoffs and wealth creation. Prometheus, 22(4), 471-474. https://doi. org/10.1017/CBO9781107415324.004.

Shapero, A., \& Sokol, L. (1982). The social dimensions of entrepreneurship, in the Encyclopaedia of entrepreneurship. In Encyclopedia of Entrepreneurship (pp. 72-90). https://doi.org/10.1093/oxfordhb/9780199546992.003.0019.

Sheeran, P. (2005). Intention-behavior relations: A conceptual and empirical review. In European Review of Social Psychology (pp. 1-36). https://doi.org/10.1002/0470013478.ch1.

Shek, D. T. L., \& Lin, L. (2015). Nurturing university students to be social entrepreneurs: Relevance of service leadership education. International Journal on Disability and Human Development. https://doi.org/10.1515/ijdhd-2015-0409.

Shirokova, G., Osiyevskyy, O., \& Bogatyreva, K. (2016). Exploring the intention-behavior link in student entrepreneurship: Moderating effects of individual and environmental characteristics. European Management Journal, 34(4), 386-399. https://doi.org/10.1016/j.emj.2015.12.007.

Smith, B. R., Kickul, J., \& Coley, L. (2010). Using simulation to develop empathy and motivate agency: An innovative pedagogical approach for social entrepreneurship education. In Handbook of Research in Entrepreneurship Education (Vol. 3, pp. 13-24). Edward Elgar Pub. 
Smith, I. H., \& Woodworth, W. P. (2012). Developing social entrepreneurs and social innovators: A social identity and selfefficacy approach. Academy of Management Learning and Education. https://doi.org/10.5465/amle.2011.0016.

Souitaris, V., Zerbinati, S., \& Al-Laham, A. (2007). Do entrepreneurship programmes raise entrepreneurial intention of science and engineering students? The effect of learning, inspiration and resources. Journal of Business Venturing, 22(4), 566-591. https://doi.org/10.1016/j.jbusvent.2006.05.002.

Swann, W. B., Chang-Schneider, C., \& Larsen McClarty, K. (2007). Do people's self-views matter? Self-concept and self-esteem in everyday life. American Psychologist, 62(2), 84-94. https://doi.org/10.1037/0003-066X.62.2.84.

Thøgersen, J. (2002). Direct experience and the strength of the personal norm —-behavior relationship. Psychology and Marketing. https://doi.org/10.1002/mar.10042.

Thompson, E. R. (2008). Development and validation of an international English big-five mini-markers. Personality and Individual Differences. https://doi.org/10.1016/j.paid.2008.06.013.

Thompson, E. R. (2009). Individual entrepreneurial intent: Construct clarification and development of an internationally reliable metric. Entrepreneurship: Theory and Practice, 33(3), 669-694. https://doi.org/10.1111/j.1540-6520.2009.00321.x.

Tierney, P., \& Farmer, S. M. (2002). Creative self-efficacy: Its potential antecedents and relationship to creative performance. Academy of Management Journal. https://doi.org/10.2307/3069429.

Tiwari, P., Bhat, A. K., \& Tikoria, J. (2017). The role of emotional intelligence and self-efficacy on social entrepreneurial attitudes and social entrepreneurial intentions. Journal of Social Entrepreneurship, 8(2), 165-185. https://doi.org/10.1080/19420676.2017.1371628.

Tkachev, A., \& Kolvereid, L. (1999). Self-employment intentions among Russian students. Entrepreneurship and Regional Development, 11(3), 269-280. https://doi.org/10.1080/089856299283209.

Trivedi, R. (2016). Does university play significant role in shaping entrepreneurial intention? A cross-country comparative analysis. Journal of Small Business and Enterprise Development, 23(3), 790-811. https://doi.org/10.1108/JSBED-10-2015-0149.

Trivedi, R. (2017). Entrepreneurial-intention constraint model: A comparative analysis among post-graduate management students in India, Singapore and Malaysia. International Entrepreneurship and Management Journal, 13(4), 1239-1261. https://doi.org/10.1007/s11365-017-0449-4.

Tshikovhi, N., \& Shambare, R. (2015). Entrepreneurial knowledge, personal attitudes, and entrepreneurship intentions among south African Enactus students. Problems and Perspectives in Management, 13(1), 152-158.

Tubbs, M. E., \& Ekeberg, S. E. (1991). The role of intentions in work motivation: Implications for goal-setting theory and research. Academy of Management Review, 16(1), 180-199. https://doi.org/10.5465/AMR.1991.4279004.

Tukamushaba, E. K., Orobia, L., \& George, B. P. (2011). Development of a conceptual model to understand international social entrepreneurship and its application in the Ugandan context. Journal of International Entrepreneurship. https://doi.org/10. 1007/s10843-011-0079-9.

Turker, D., \& Selcuk, S. S. (2009). Which factors affect entrepreneurial intention of university students? Journal of European Industrial Training, 33(2), 142-159. https://doi.org/10.1108/03090590910939049.

van Gelderen, M., Brand, M., van Praag, M., Bodewes, W., Poutsma, E., \& van Gils, A. (2008). Explaining entrepreneurial intentions by means of the theory of planned behaviour. Career Development International, 13(6), 538-559. https://doi. org/10.1108/13620430810901688.

van Gelderen, M., \& Jansen, P. (2006). Autonomy as a start-up motive. Journal of Small Business and Enterprise Development, 13(1), 23-32. https://doi.org/10.1108/14626000610645289.

Varamäki, E., Tornikoski, E., Joensuu, S., Ristimäki, K., Blesa, A., \& Ripolles, M. (2013). Entrepreneurial intentions among higher education students in Finland and Spain: Developing and piloting a survey instrument. International Journal of Information Systems in the Service Sector, 5(4), 1-16. https://doi.org/10.4018/ijisss.2013100101.

Vidal, I. (2005). Social Enterprise and social Inclusion: Social Enterprises in the Sphere of Work Integration. International Journal of Public Administration. https://doi.org/10.1081/PAD-200067347.

Vining, J., \& Ebreo, A. (1989). An evaluation of the public response to a community recycling education program. Society \& Natural Resources, 2(1), 23-36. https://doi.org/10.1080/08941928909380673.

Wang, J. H., Chang, C. C., Yao, S. N., \& Liang, C. (2016). The contribution of self-efficacy to the relationship between personality traits and entrepreneurial intention. Higher Education. https://doi.org/10.1007/s10734-015-9946-y.

Watchravesringkan, K. T., Hodges, N. N., Yurchisin, J., Hegland, J., Karpova, E., Marcketti, S., \& Yan, R. N. (2013). Modeling entrepreneurial career intentions among undergraduates: An examination of the moderating role of entrepreneurial knowledge and skills. Family and Consumer Sciences Research Journal, 41(3), 325-342. https://doi.org/10.1111/fcsr.12014.

Williams, D. (2006). On and off the 'net: Scales for social Capital in an Online era. Journal of Computer-Mediated Communication. https://doi.org/10.1111/j.1083-6101.2006.00029.x.

Wilson, F., Kickul, J., \& Marlino, D. (2007). Gender, entrepreneurial self-efficacy, and entrepreneurial career intentions: Implications for entrepreneurship education. Entrepreneurship: Theory and Practice, 31(3), 387-406. https:/doi.org/10.1111/j.1540-6520.2007.00179.x.

Xi, J. M., Kraus, S., Filser, M., \& Kellermanns, F. W. (2013). Mapping the field of family business research: Past trends and future directions. International Entrepreneurship and Management Journal, 11(1), 113-132. https://doi.org/10.1007/s11365-013-0286-z.

Yiu, D. W., Wan, W. P., Ng, F. W., Chen, X., \& Su, J. (2014). Sentimental drivers of social entrepreneurship: A study of China's Guangcai (glorious) program. Management and Organization Review. https://doi.org/10.1111/more.12043.

Zacharakis, A. L., Meyer, G. D., \& DeCastro, J. (1999). Differing perceptions of new venture failure : A matched exploratory study of venture capitalists. Journal of Small Business Management, 37(3), 1-14 Retrieved from https://www.scopus.com/record/display. uri?eid=2-s2.0-0033240243\&origin=inward\&txGid=DCD1 C94E7E233FCC104746C19CCA09D5.wsnAw8kcdt7IPYLO0V48gA\%3A1.

Zadek, S., \& Thake, S. (1997). Send in the social entrepreneurs. New Statesman. https://doi.org/10.1080/07351698809533738.

Zhang, Y., Duysters, G., \& Cloodt, M. (2014). The role of entrepreneurship education as a predictor of university students' entrepreneurial intention. International Entrepreneurship and Management Journal, 10(3), 623-641. https://doi.org/10.1007/ s11365-012-0246-z.

Zhao, H., Seibert, S. E., Hills, G. E., \& Seibert, S. E. (2005). The mediating role of self-efficacy in the development of entrepreneurial intentions. Journal of Applied Psychology, 90(6), 1265-1272. https://doi.org/10.1037/0021-9010.90.6.1265.

\section{Publisher's Note}

Springer Nature remains neutral with regard to jurisdictional claims in published maps and institutional affiliations. 